\title{
NCCN Task Force Report: Estrogen Receptor and Progesterone Receptor Testing in Breast Cancer by Immunohistochemistry
}

D. Craig Allred, MD; Robert W. Carlson, MD; Donald A. Berry, PhD; Harold J. Burstein, MD, PhD; Stephen B. Edge, MD; Lori J. Goldstein, MD; Allen Gown, MD; M. Elizabeth Hammond, MD; James Dirk Iglehart, MD; Susan Moench, PhD; Lori J. Pierce, MD; Peter Ravdin, MD, PhD; Stuart J. Schnitt, MD; and Antonio C. Wolff, MD

\begin{abstract}
Key Words
Breast cancer, immunohistochemistry, estrogen receptor, progesterone receptor, endocrine therapy, NCCN Clinical Practice Guidelines in Oncology, technical validation, clinical validation, false-negative rate, quality control, quality assurance
\end{abstract}

\footnotetext{
Abstract

The NCCN Task Force on Estrogen Receptor and Progesterone Receptor Testing in Breast Cancer by Immunohistochemistry was convened to critically evaluate the extent to which the presence of the estrogen receptor (ER) and progesterone receptor (PgR) biomarkers in breast cancer serve as prognostic and predictive factors in the adjuvant and metastatic settings, and the ability of immunohistochemical (IHC) detection of ER and PgR to provide an accurate assessment of the expression of these biomarkers in breast cancer tumor tissue. The task force is a multidisciplinary panel of 13 experts in breast cancer who are affiliated with NCCN member institutions and represent the disciplines of pathology, medical oncology, radiation oncology, surgical oncology, and biostatistics. The main overall conclusions of the task force are ER is a strong predictor of response to endocrine therapy; ER status of all samples of invasive breast cancer or ductal carcinoma in situ (DCIS) should be evaluated by IHC; IHC measurements of PgR, although not as important clinically as ER, can provide useful information and should also be performed on all samples of invasive breast cancer or DCIS; IHC is the main testing strategy for evaluating ER and PgR in breast cancer and priority should be given to improve the quality of IHC testing methodologies; all laboratories performing IHC assays of ER and PgR should undertake formal validation studies to show both technical and clinical validation of the assay in use; and all laboratories performing IHC assays of hormone receptors in breast cancer should follow additional quality control and assurance measures as outlined in the upcoming guidelines from the American Society of Clinical Oncology and College of American Pathologists. (JNCCN 2009;7[Suppl 6]:S1-S21)
}

\section{Task Force Rationale}

Estrogen receptor (ER) status is a powerful predictor of breast cancer response to endocrine therapy. Results from the Early Breast Cancer Trialists' Collaborative Group (EBCTCG) overview show that tamoxifen substantially reduces risk for breast cancer recurrence and death across all age groups in patients with ER-positive early-stage breast cancer, whereas patients with ERnegative disease do not show benefit from tamoxifen. ${ }^{1,2}$ ER status also predicts response to endocrine therapy in the metastatic setting., ${ }^{3,4}$ In addition, retrospective evidence suggests that the benefits of chemotherapy are significantly higher in patients with ER-negative compared with ER-positive early-stage, node-positive breast cancer, indicating that information on ER tumor status can also impact treatment decision-making regarding adjuvant chemotherapy.,6

Virtually all determinations of the ER and progesterone receptor $(\mathrm{PgR})$ status of breast cancers are performed today using immunohistochemistry (IHC) on formalin-fixed, paraffin-embedded tissue. Nevertheless, several problems have been associated with IHC tests of these hormone receptors, the most important being a high false-negative rate. For example, the false-negative rate of samples evaluated for ER by IHC in one consult practice was estimated at approximately 20\% to $30 \%$ (with possibly higher rates for PgR; Craig Allred, $\mathrm{MD}$, personal communication). This problem has recently received increased attention after reports of false-negative rates of $30 \%$ to more than $60 \%$ in several different settings. ${ }^{7-11}$

In contrast, results from ECOG E2197 study showed a $90 \%$ concordance when IHC test results of 
ER in breast cancer tissue samples evaluated in local laboratories were compared to results obtained in a central laboratory. ${ }^{12}$ Members of the task force acknowledged that although more typical falsenegative rates of IHC determinations of ER status in breast cancer may not be represented by the more extreme cases reported, this is nonetheless a relatively common problem (i.e., estimated at $20 \%$ in the United States).

Ramifications of a false-negative test result for ER/PgR tumor status are potentially devastating for women with breast cancer, resulting in the withholding of a highly effective therapy with a good safety profile (Figure 1). Furthermore, the potential impact of decreasing the number of false-negative results is great because approximately $70 \%$ to $80 \%$ and more than $50 \%$ of women with breast cancer in higherincome countries have ER-positive and PgR-positive disease, respectively, ${ }^{13-15}$ although these values may not be as high in some lower-income countries.

The task force was formed to facilitate interaction between pathologists and clinicians to enhance their cooperation in addressing the existing problems related to hormone receptor testing in breast cancer. The purpose of the following task force report is several-fold:

- To provide clinicians with insight into strengths and weakness of tests used to determine ER and PgR status in breast cancer, with emphasis on
IHC tests of these hormone receptors.

- To provide pathologists with insight into the impact of results of ER and PgR testing on clinical decision-making for patients with breast cancer.

- To provide pathologists with recommendations for improving the quality of IHC testing of ER and PgR in breast cancer.

- To provide clinicians with information to assess quality and interpret results of IHC tests of ER and PgR in breast cancer.

- To incorporate information and recommendations into NCCN Clinical Practice Guidelines in Oncology: Breast Cancer (to view the most recent version of these guidelines, visit the NCCN Web site at www.nccn.org).

\section{Task Force Process}

All 13 members of the task force are affiliated with NCCN member institutions, and some of the participants are also members of the NCCN Breast Cancer Guidelines Panel. Medical specialties of the participants included pathology, medical oncology, surgical oncology, radiation oncology, and biostatistics. A formal meeting agenda was developed by the task force chairs before the meeting, and individual participants presented focused didactic presentations based on identification of key references, followed by group discussion. An evidence-based

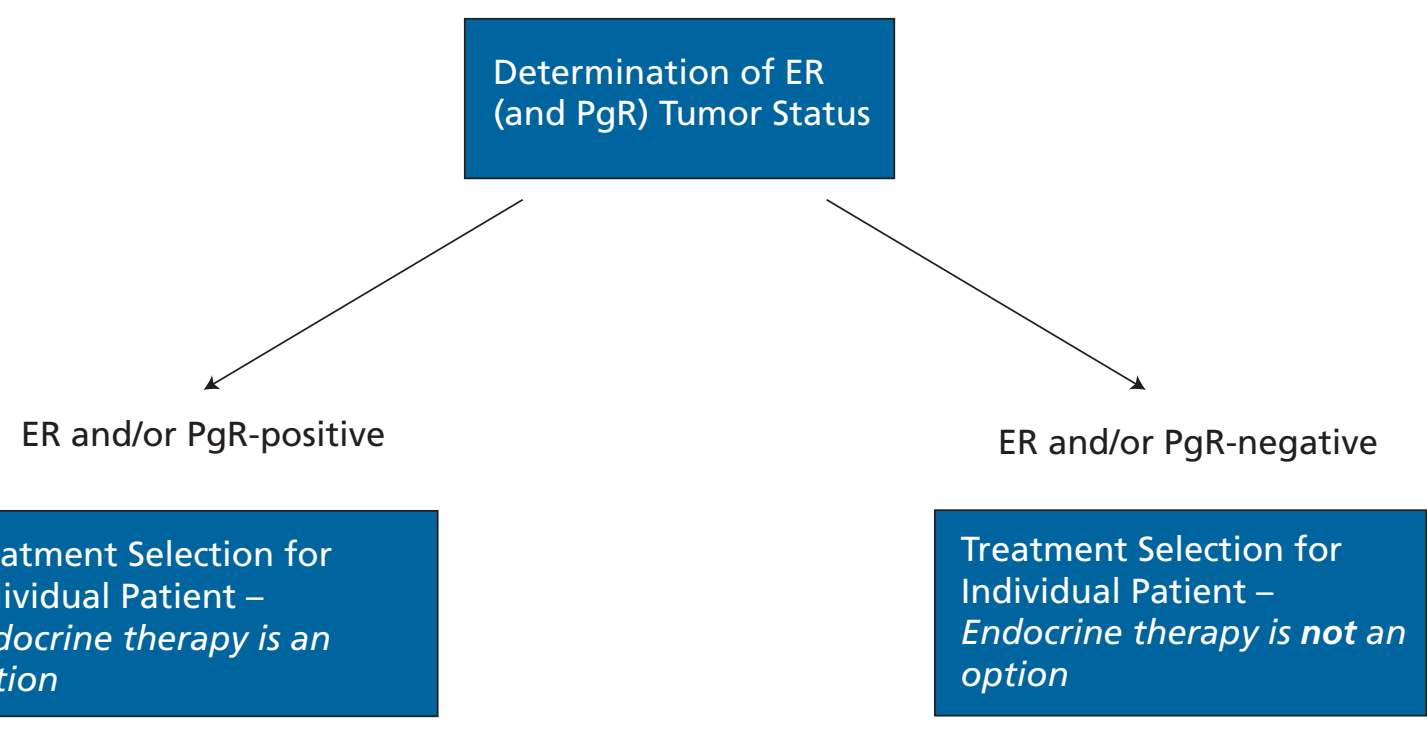

Figure 1 Detection of ER (estrogen receptor; and PgR [progesterone receptor]) in breast cancer tissue determines whether a patient is a candidate for endocrine therapy. 
consensus approach ${ }^{16}$ was used to formulate recommendations relating to the pathologic and clinical application of the evidence to the evaluation and care of patients with breast cancer. In areas of controversy, this process extended beyond the meeting to achieve consensus. Draft versions of this report were circulated among all task force members for review and comment.

\section{Biology of Steroid Hormone Receptors}

Estrogen and progesterone are steroid hormones that play a central role in regulating the growth and differentiation of normal breast epithelium and in promoting the development of breast cancer (especially in a setting of prolonged and/or high levels of exposure). The functions and effects of these hormones are mediated through the binding and activating of specific receptors. An ER, first identified in 1962, ${ }^{17-19}$ was subsequently named ER-alpha after the more recent discovery of another ER, termed ER-beta. ${ }^{20,21}$ Two different genes encode for the 2 types of ER. ${ }^{22}$ Two PgRs, the isoforms PgR-A and PgR-B (the former being a truncated form of the latter), have also been identified and characterized. ${ }^{23,24}$

ERs and PgRs are members of the class I nuclear receptor superfamily. Radiographic crystallographic studies have shown that ER-alpha, ER-beta, and isoforms of PgR have similar 3-dimensional structures, particularly with respect to protein domains involved in receptor dimerization, and the binding of ligand, DNA, and transcriptional cofactors. ${ }^{25,26}$ This section focuses on the biology of ER-alpha, the most well studied of these receptors. Other hormone receptors (e.g., ER-beta and PgR, and its isoforms) participate in regulating some of the same functions as ER-alpha, but they also possess distinct properties. When not otherwise specified, "ER" refers to ERalpha and PgR refers to both PgR-A and PgR-B.

ER-alpha is a soluble protein, with a molecular weight of $66,000 \mathrm{Da},{ }^{27}$ although many smaller so-called splice variants, formed through posttranscriptional modification, are translated into lower molecular weight forms of the protein..$^{28,29}$

The classic mechanism of action for ER-alpha is based on its ability to act as a ligand-dependent transcription factor. ${ }^{25}$ This process is initiated by diffusion of the hydrophobic estrogen molecule across the plasma membrane of the cell. Estrogen then binds to ER-alpha located in either the cytoplasm or the nucleus of the cell. Ligand binding induces a protein conformational change that facilitates receptor dimerization, with subsequent translocation of the cytosolic receptor dimer across the nuclear membrane. The receptor dimer within the nucleus is able to bind to specific transcriptional cofactors and interact either directly or indirectly with DNA through association with other DNA-binding proteins to activate or repress the transcription of estrogen-responsive genes (see Figure 2). Manifestation of the transcriptional impact of this type of regulation has been estimated to require a timeframe of minutes to days.

Some estrogen-induced cellular processes also occur over much shorter periods (i.e., seconds to minutes). Although first reported more than 30 years ago, experts have recently established that ER can also associate with the plasma membrane of the cell. ${ }^{30}$ Evidence shows that protein palmitoylation of the receptor facilitates its association with caveolin-1, a "lipid raft" protein that is believed to play a role in membrane trafficking. ${ }^{31}$ This, in turn, promotes localization of the receptor to the plasma membrane. ${ }^{32}$ The membrane-bound form of ER is known to be capable of initiating rapid cellular signaling on estrogen binding through activation of particular kinases. ${ }^{33,34}$ These signaling processes ultimately influence nongenomic cellular processes and genomic cellular responses through "crosstalk" with other signaling cascades or production of second messengers (see Figure 2), resulting in stimulation of cellular proliferation and suppression of apoptosis. ${ }^{25,34}$

Phosphorylation of the receptor at specific amino acid residues can modulate its activity in nuclear and plasma membrane-bound environments. ${ }^{25,35}$ A phosphorylated form of membrane-bound ER is present in invasive breast cancer but not in ductal carcinoma in situ (DCIS) or normal breast tissue. ${ }^{36}$ Phosphorylated forms of ER attached to the plasma membrane or residing in the nucleus may be capable of initiating cell signaling processes independent of bound ligand. . $^{35,37}$

\section{Endocrine Therapy: Mechanisms of Action}

Endocrine therapies for the treatment of breast cancer include a wide variety of endocrine agents, including the antiestrogens, tamoxifen and fulves- 
NCCN Task Force Report

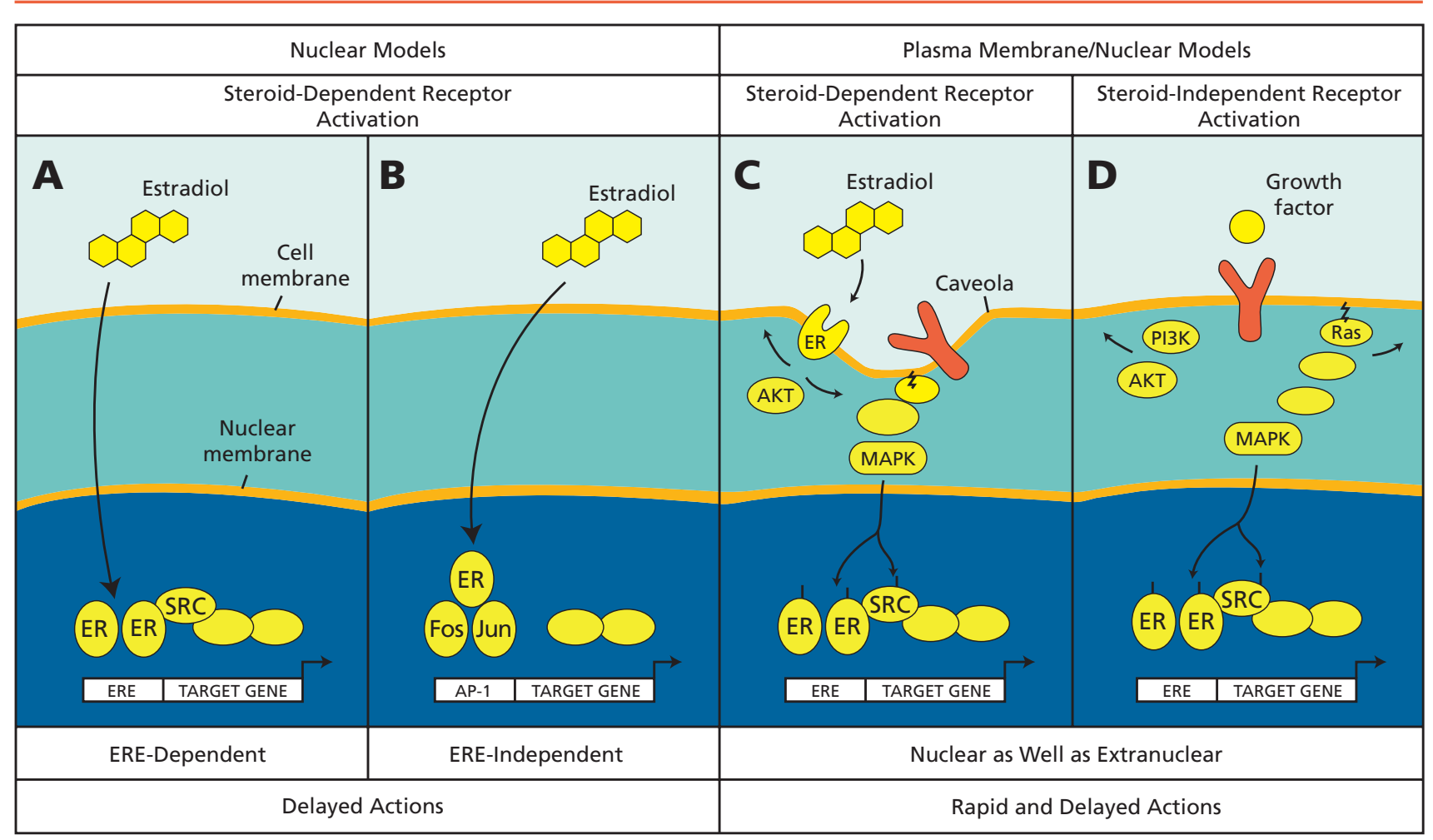

Figure 2 Model of estrogen action in target cells. In many prevailing models (A, B), estrogen freely enters all cells and is retained only in those cells in which it binds to its receptor. (A) In the nucleus, estrogen binding to ER (estrogen receptor) is believed to favor enhanced association with coactivator proteins and certain estrogen-responsive elements (EREs) on specific genes, leading to selective gene transcription. (B) This nuclear model accounts for ERE-independent genomic activation; ER interacts with activating protein-1 (AP-1) to facilitate gene transcription. (C) In this model, estrogen binds to a plasma-membrane associated ER to promote hormonal responses through another pathway that "crosstalks," or interacts directly with, a genomic mechanism. (D) In this steroidindependent model of estrogen action, activation of ER occurs through mediation by growth factor receptor signaling pathways.

Abbreviations: AKT, protein kinase B; Fos and Jun, transcription factors; SRC, steroid receptor coactivator; MAPK, mitogen-activated protein kinases, P13K, phosphatidylinositol-3-kinase.

From Pietras RJ. Biologic basis of sequential and combination therapies for hormone-responsive breast cancer. Oncologist 2006;11:704-717; with permission.

trant, and reversible (e.g., letrozole, anastrozole) and irreversible (e.g., exemestane) aromatase inhibitors. Tamoxifen, the most extensively studied of these therapies, is converted by the enzyme CYP2D6 to endoxifen, its active metabolite, which then competes with estrogen for the ligand binding site of ER. Tamoxifen acts as either an estrogen antagonist or agonist, depending on the species, target tissue, and end point studied. For example, tamoxifen displays antiestrogen activity in breast tissue but acts as an estrogen agonist with respect to bone and endometrial tissue. ${ }^{38,39}$ Fulvestrant also binds to ER at the estrogen binding site but is considered to be a pure antiestrogen without agonist activity in any organ. It is known to interfere with several cellular processes involving ER, such as the binding of certain cofactors, receptor dimerization, and translocation of the receptor to the nucleus. ${ }^{40,41}$ Reversible nonsteroidal and irreversible steroidal aromatase inhibitors do not interact directly with ER. Instead, they interfere with the enzymatic conversion of androgens to estrogen, thereby lowering the estrogen concentration available for binding to ER in tissues. ${ }^{42}$

Importantly, not all ER-positive breast cancers respond to endocrine therapy. In the setting of metastatic breast cancer, almost all tumors exhibiting a response to endocrine therapy will eventually experience disease progression despite continued treatment. The molecular basis for endocrine refractory/ resistant disease is unclear and likely to be diverse. ${ }^{43,44}$ Proposed mechanisms include post-translational modification of ER and its transcriptional co-activators and repressors, and crosstalk with other signaling pathways. The 2 processes may be linked. 
For example, breast cancer tumors that overexpress human epidermal growth factor receptor 2 (HER2) are more likely to be resistant to endocrine therapy compared with HER2-negative tumors. ${ }^{45}$ HER2 overexpression has been reported to trigger signaling for increased ER phosphorylation. ${ }^{46}$ Phosphorylation at particular sites on ER may increase the binding affinity of ER for estrogen, interfere with endoxifenER association, or provide for ligand-independent activation of ER. ${ }^{34,35}$ Other possible causes of resistance to endocrine therapy may involve an increase in aromatase levels. ${ }^{34}$

\section{Methods of Detecting ER and PgR in Breast Cancer}

Most ER and PgR testing is performed using IHC assays, although other methods of detecting ER and $\mathrm{PgR}$ in breast cancer tissue are available. Several fundamental principles of tumor marker testing should be considered when addressing ER and PgR testing of breast cancer. ${ }^{47-51}$

First, the most important purpose of evaluating the status of a tumor marker is to predict whether a patient is likely to experience a clinically important benefit from a particular therapy. ${ }^{52}$ In the case of endocrine therapy, this would ideally involve an assessment of the functionality of ER and PgR, including an evaluation of the activated downstream proteins of these receptors. None of the currently available tests provide this assessment, although expression of $\mathrm{PgR}$ is known to be regulated by estrogen-activated ER; hence, a PgR-positive status is one indication of functional ER. ${ }^{53,54}$ Nevertheless, measurement of ER and PgR status in breast cancer tissue meets the criterion of usefulness with respect to clinical decision making (see Clinical Issues, page S-9).

Second, the test used to measure the tumor marker should be technically validated. A technically validated assay is sensitive, specific, and reproducible and allows for a uniform interpretation of results. ${ }^{52}$ The process of technical validation involves measuring the degree of concordance between tumor marker results obtained using the test assay and another assay previously shown to be technically valid. Furthermore, technical validation of an IHC test against another technically valid IHC method for assessing ER status involves using the same method to quantify and interpret signals in both assays.
Finally, measurement of a tumor marker using a technically validated assay should be clinically validated in that it should be calibrated to identify groups of patients with significantly different risks of relapse, survival, or treatment response, preferably as shown in multiple randomized clinical trials. ${ }^{52}$ In other words, it involves correlation between clinical outcome and the status of the tumor marker as measured by a particular assay; this information is necessary to establish a clinical cutoff value separating a positive from a negative result. In fact, the term clinical validation can be applied to both a particular assay and the biomarker that is measured in the context of that assay. Some specific examples of the processes used to technically and clinically validate particular IHC assays of ER and PgR are described later.

ER has been measured in breast cancer tissue for more than 35 years. In 1973, McGuire ${ }^{55}$ used a dextran-coated charcoal ligand assay to show the broad concentration range of ER in breast cancer tissue, and LB assays were routinely used for this purpose for many years. An advantage to using the LB assay for measuring ER is that it is a quantitative method (showing a continuum of ER concentrations in breast cancer tissue) that has been correlated with clinical outcome..$^{52,56,57}$ Nevertheless, the LB assay is difficult and expensive to perform. Other disadvantages include the need for large frozen specimens and radioisotopes, and the fact that receptors occupied by endogenous substances are not detectable. Perhaps most importantly, the LB assay is a "grind-up" method that measures ER in all cells of the sample tissue (i.e., tumor and normal breast tissue).

In 1985 , McCarty et al..$^{58,59}$ showed a correlation between measurements of ER in breast cancer tissue obtained using the LB assay and those using an IHC assay with a highly specific monoclonal antibody for the receptor. The methodology of IHC testing is outlined in Table 1 for ER, although the same general schema applies to IHC testing of PgR. The IHC test is typically performed on thin slices of formalin-fixed, paraffin-embedded tissue. An example of a stained specimen of breast cancer tumor tissue processed according to the IHC assay for ER is shown in Figure 3.

Advantages of IHC over the LB assay include the ability to be performed inexpensively on small specimens, frozen or fixed, without radioactivity. In addition, it allows pathologists to restrict their evaluation of ER and PgR status to tumor cells only..$^{58-60}$ 
Table 1 Shared Elements of IHC Assays of ER and PgR

- $\quad$ Sample is formalin-fixed paraffin-embedded tissue

- Antigen retrieval process (many methods)

- $\quad$ ER or PgR specific antibody (several/well validated)

- Generation of a color signal

- Quantification of signal

- Interpretation of signal

Abbreviations: ER, estrogen receptor; IHC, immunohistochemistry; PgR, progesterone receptor.

IHC tests of hormone receptors provide either dichotomous or more quantitative results. Several IHC systems have been devised to score results from IHC tests of ER in breast tissue, including the Allred score. The Allred score provides an overall score of either 0 or 2-8 through summation of a proportion score and an intensity score; first the proportion of cells with positive staining is estimated with a score of 0 to 5 , then an average staining intensity is determined with a score of 0 to $3 .^{52}$ Another method, called the "H-score," provides an overall score $\left(\mathrm{O}_{-}\right.$ 300) based on the sum of weighted percentages of cells stained as weak, moderate, or strong. ${ }^{45,61,62} \mathrm{~A}$ dichotomous interpretation of results (i.e., positive

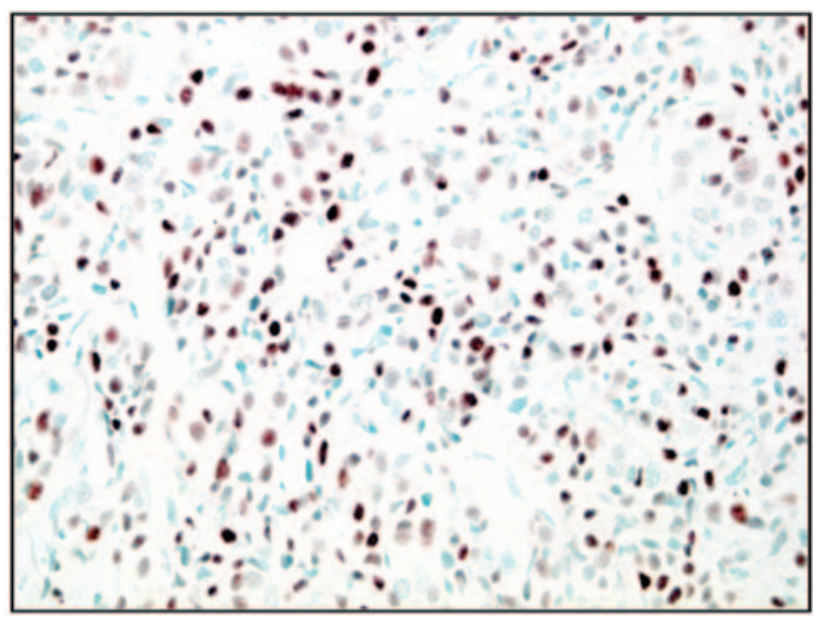

Figure 3 Representative invasive breast cancer sample with immunostaining. ER-positive cells are stained brown or black. Note cells characterized by the absence or presence of stain and variations in the stain intensity of stained cells. Using the Allred score as an example, this sample would have a proportion score of 4 (1/3-2/3 "positive" cells) and an average intensity score of 2 (intermediate) to give a final Allred score of 6/8. Courtesy of D. Craig Allred, MD. vs. negative) is also used., 5,13,63,64 Automated systems are also available for the quantitative analysis of ER expression in breast cancer tissue. ${ }^{65}$

Studies evaluating the correlation of measurements of ER and PgR in breast cancer tissue performed using either IHC testing or the LB assay (as a gold standard) have typically shown discordance rates ranging from $10 \%$ to $30 \% .{ }^{60,66-71}$ In some studies, IHC was found to be superior to the LB assay in predicting clinical response to endocrine therapy in certain patient populations, ${ }^{66,69-71}$ although other studies showed the LB assay to be more accurate. ${ }^{60,72}$

In a study published in 1999, Harvey et al. ${ }^{66}$ described the development of a standardized procedure for detecting ER in breast tissue using IHC, and provided detailed information on the processes followed for technical and clinical validation of the assay in a large population of women with breast cancer (Figure 4). The original study used samples prepared in an unconventional manner (particulate frozen tissue left over from the LB assay, which was concentrated using centrifugation, fixed in $10 \%$ neutral buffered formalin for 8-12 hours, and processed to formalinfixed, paraffin-embedded tissue samples). However, this procedure has been validated in other studies based on conventionally prepared samples. ${ }^{14,73-76}$

The 6F11 monoclonal antibody to ER was shown to be sensitive and specific for detecting ER in tumor cells using IHC through a comparison of assay results from IHC and LB assays performed on the same tumor samples; assay concordance was $86 \%$. Using the Allred method, a range of IHC scores were observed, representing a nearly linear correlation between ER concentrations detected using IHC and the LB assay. A cutoff distinguishing a positive from a negative IHC result was determined through calibrating assay results with clinical outcome (i.e., disease-free survival in patients treated with adjuvant tamoxifen). In addition, a distribution of IHC scores was shown to correlate with a distribution of responses to tamoxifen. Interestingly, 3 was the lowest score predicting for a positive response to hormonal therapy, corresponding to as few as $1 \%$ to $10 \%$ of weakly positive tumor cells.

Another IHC assay uses a cocktail of ER.2.123 and 1D5 as primary antibodies. The test kit of this assay is the only FDA-approved IHC assay of ER in breast cancer; ${ }^{77}$ FDA approval was made after this assay was carefully validated against that of Harvey et al. ${ }^{66,78}$ 
A

\begin{tabular}{|c|c|c|}
\hline$\underline{\text { IHC Score }}$ & $\underline{\text { LBA }(\mathrm{fmol} / \mathrm{mg})}$ & \#Patients $(\%)$ \\
\hline 0 & 10 & $517(26 \%)$ \\
\hline 2 & 50 & $67(3 \%)$ \\
\hline 3 & 59 & $117(6 \%)$ \\
\hline 4 & 67 & $190(10 \%)$ \\
\hline 5 & 104 & $320(16 \%)$ \\
\hline 6 & 141 & 370 (19\%) \\
\hline 7 & 193 & $318(16 \%)$ \\
\hline 8 & 282 & $83(4 \%)$ \\
\hline
\end{tabular}

C
B

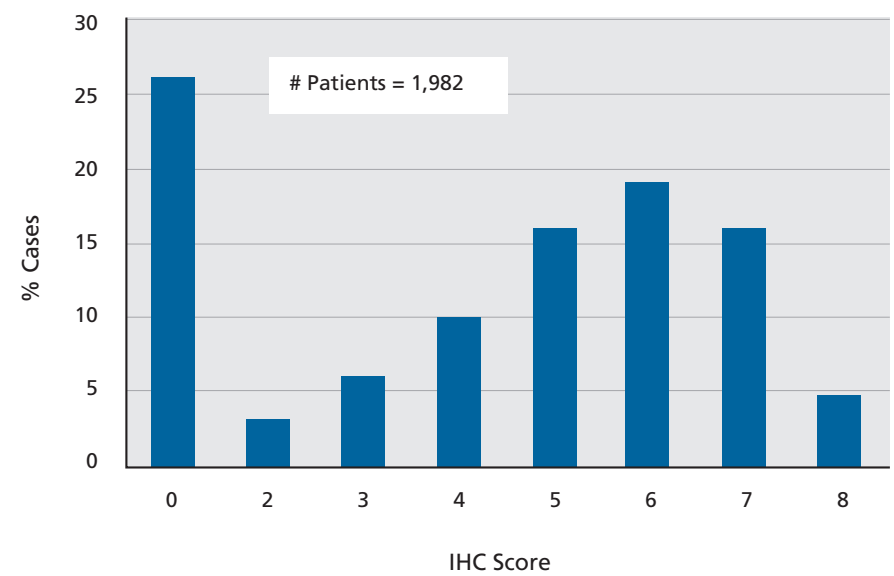

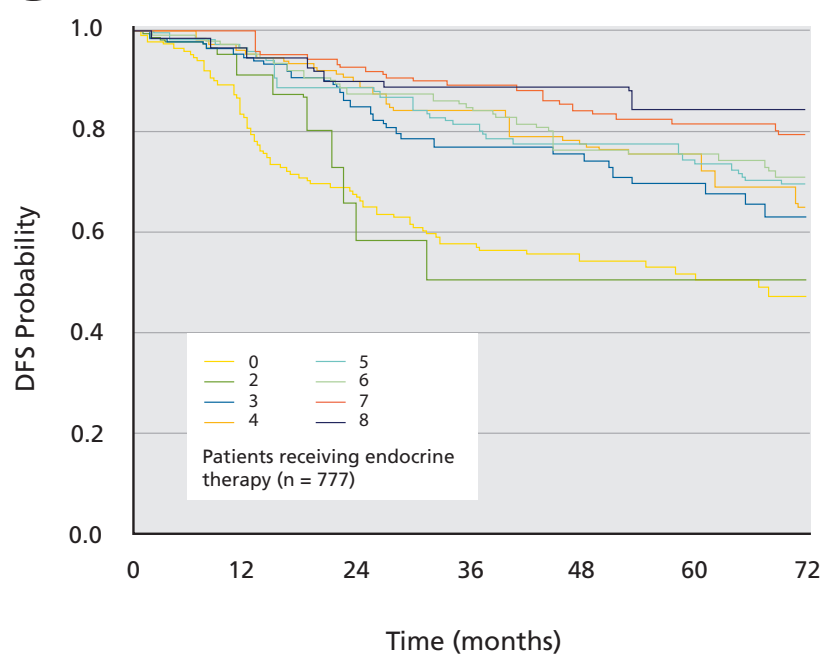

Figure 4 Example of study showing relationship of ligand binding (LB) assay measurements, distribution of IHC scores, and clinical response. (A) Comparison of measurements of ER as determined by immunohistochemistry (IHC) and LB assay. (B) Distribution of IHC scores using the Allred scoring method. (C) Comparison of disease-free survival curves for all possible Allred IHC scores allows for determination of cutoff score distinguishing a positive from a negative result. A positive score is Allred score $\geq 3$ (indicating $>1 \%$ of cells with weak staining is a positive result).

Panels A and C from Harvey JM, Clark GM, Osborne CK, Allred DC. Estrogen receptor status by immunohistochemistry is superior to the ligand-binding assay for predicting response to adjuvant endocrine therapy in breast cancer. J Clin Oncol 1999;17:1474-1481. Reprinted with permission. (C) 2008 American Society of Clinical Oncology. All rights reserved.

Other examples of standardized, comprehensively validated IHC assays for ER were reported by Cheang et al. ${ }^{72}$ In this study, tissue microarrays were constructed from formalin-fixed tumor specimens from a large population of women in British Columbia with newly diagnosed invasive breast cancer. Most of the specimens had previously been evaluated for ER using the LB assay. Two different IHC assays were performed on these samples using the SP1 and 1D5 monoclonal antibodies to ER. In most cases, results were reported as either negative $(<1 \%$ of cells stained) or positive ( $\geq 1 \%$ of cells stained). This cut- off value was subsequently shown to correlate with overall survival in a retrospective study of patients from the NSABP B-09 trial in which the ER status of tumor samples was retested using an IHC method and compared with results obtained with other testing methods (e.g., LB assay). ${ }^{64}$

A comparison with results from the LB assay showed the IHC assays using SP1 and 1D5 antibodies to be sensitive and specific for detecting ER in breast tumor tissue. Concordance of ER tumor status with respect to the LB assay was $86.8 \%$ and $80.5 \%$ for the IHC assay using SP1 and 1D5 antibodies, re- 
spectively. In addition, both IHC assays and the LB assay were shown to be good predictors of breast cancer-specific and relapse-free survival.

Because not all patients with ER-positive disease benefit from endocrine therapy, one of the initial driving forces behind the evaluation of tumor PgR status in breast cancer was to identify additional markers of endocrine therapy response. Several comprehensively validated IHC assays for PgR have been developed. ${ }^{11,45,70}$ Table 2 provides a list of standard IHC methods for evaluating ER and PgR in breast cancer tumor samples, which have also been comprehensively validated. These assays include those that have been clinically validated in patients treated with tamoxifen and an aromatase inhibitor.

Tests for measuring ER and PgR in breast cancer are evolving. The task force recognizes that new methods are being developed that may replace IHC at some point in the future. Nevertheless, IHC is likely to be the main testing strategy for the evaluation of these receptors in breast cancer for several years, and therefore it is the central focus of this report.

Promising new strategies being developed for the measurement of ER and PgR in breast cancer tissue involve a fluorescence-detected IHC assay and several gene-based assays. For example, fluorescent probes used in an IHC assay using an automated image immunofluorescence detection system (AQUA, Automated Quantitative Analysis) ${ }^{79}$ have been reported to have an advantage over traditionally used chromogenic (i.e., brown) stains in that they can provide a broader dynamic range for detecting the wide spectrum of ER concentrations in breast tissue. ${ }^{79-82}$

Other alternative methods for measuring ER and/or PgR in breast cancer tissue include genebased assays evaluating mRNA expression. High concordance rates were reported when quantitative ER and PgR results obtained using reverse-transcription polymerase chain reaction (RT-PCR) methods according to the Oncotype DX assay (and using predetermined positive/negative cutoff points ${ }^{83}$ ) were compared with results of IHC assays performed locally and centrally. ${ }^{12}$ The Oncotype DX assay has been validated $^{84,85}$ and results of a recent study comparing measurements of ER using quantitative RT-PCR and IHC suggest that the former methodology may be superior in predicting breast cancer recurrence. ${ }^{12,86}$ In addition, a study comparing determination of ER and PgR breast cancer tumor status in fresh-frozen tissue using microarray expression analysis with custom-made arrays showed good concordance for ER compared with IHC (concordance rate, 94\%), although assay agreement with IHC was lower for PgR (concordance rate, $80 \%$ ). ${ }^{87}$

Another approach under investigation involves measuring the levels of gene expression regulated by estrogen in estrogen receptor-positive breast cancer tissue. ${ }^{88}$ A disadvantage of using gene expression assays to measure ER and PgR in breast cancer tissue is that they are "grind-up" methods that lack the ability of IHC to define the cytologic/histologic localization of the receptors. The cost and availability of these assays and the possibility of true biologic dis-

Table 2 Comprehensively Validated IHC Assays for Evaluating ER and PgR in Breast Cancer

\begin{tabular}{|c|c|c|}
\hline \multirow[b]{2}{*}{ Assay Reference } & Cutoff Value Used to Define "Positive" Result & \multirow[b]{2}{*}{ Primary Antibody } \\
\hline & IHC Assays for ER & \\
\hline Harvey et al. ${ }^{66}$ & Allred Score $\geq 3(1 \%-10 \%$ weakly positive cells) & $6 \mathrm{~F} 11$ \\
\hline $\begin{array}{l}\text { Regan et al., }{ }^{69} \\
\text { and Viale et al. } .^{5,11}\end{array}$ & $1 \%-9 \%$ (low) and $\geq 10 \%$ (high) & 1D5 \\
\hline Cheang et al. ${ }^{72}$ & $\geq 1 \%$ & SP1 \\
\hline Phillips et al. ${ }^{78}$ & Allred Score $\geq 3(1 \%-10 \%$ weakly positive cells) & ER.2.123 + 1D5 (cocktail) \\
\hline \multirow[t]{2}{*}{ Dowsett et al. ${ }^{45}$} & H-score $>1(\geq 1 \%)$ & $6 \mathrm{~F} 11$ \\
\hline & IHC Assays for PgR & \\
\hline Mohsin et al. ${ }^{70}$ & Allred Score $\geq 3(1 \%-10 \%$ weakly positive cells) & 1294 \\
\hline $\begin{array}{l}\text { Regan et al., } 69 \\
\text { and Viale et al. }{ }^{5,11}\end{array}$ & $1 \%-9 \%$ (low) and $\geq 10 \%$ (high) & $1 \mathrm{~A} 6$ \\
\hline Phillips et al. ${ }^{78}$ & Allred Score $\geq 3(1 \%-10 \%$ weakly positive cells) & 1294 \\
\hline Dowsett et al. ${ }^{45}$ & $\geq 10 \%$ & 312 \\
\hline
\end{tabular}


cordances between protein and mRNA ${ }^{12}$ are also potential impediments to more widespread use of these assays in evaluating hormone receptors in breast cancer tissue.

\section{ER/PgR Testing}

\section{Clinical Issues: Correlation of ER/PgR with Clinical Outcome in the Absence and Presence of Therapy}

Both individually and across the spectrum of breast cancer, breast cancers show a high degree of molecular heterogeneity. ${ }^{89}$ Therefore, attempts to correlate a single tumor marker with clinical outcome are likely to have limitations. Furthermore, the clinical studies cited later used many different assay methods to determine the ER and PgR status in samples of breast cancer tumors and, in some cases, the level of validation of these tests is unclear.

ER/PgR as Prognostic Factors in Breast Cancer: A prognostic factor provides information on the intrinsic biology and natural history of disease. In breast cancer, it has been defined as a "measurement available at the time of diagnosis or surgery that is associated with clinical outcome in the absence of systemic adjuvant therapy." ${ }^{\text {T0 }}$ The prognostic significance of ER and PgR in breast cancer is still being debated. Many studies addressing the prognostic significance of hormone receptors in patients with early-stage breast cancer are confounded by the administration of adjuvant therapy. In addition, small sample sizes, short follow-up, differences in clinical characteristics of patient populations, and exclusion of certain pathologic or clinical features from statistical analyses can contribute to different findings on the prognostic significance of ER and PgR in breast cancer. ${ }^{12}$

Some evidence shows that ER and/or PgR are favorable prognostic factors in patients not undergoing adjuvant therapy. ${ }^{90-92}$ For example, Bardou et al. ${ }^{92}$ showed ER and PgR to have a modest independent prognostic benefit over a 3-year period when evaluated in women with breast cancer who did not undergo adjuvant therapy. In a population-based study, positive ER tumor status correlated with improvements in breast cancer-specific survival and recurrence-free survival over a long-term period in women with breast cancer not treated with adjuvant therapy. ${ }^{72}$ However, the survival advantage for patients with ER-positive disease decreased over time and crossed with the curve representing ER-negative patients at 18 years.

Furthermore, several additional studies with long follow-up confirm that the initial prognostic advantages of tumor ER-positivity diminish over time, suggesting that this tumor marker may provide information on the rate at which disease recurs but not on the long-term outcome of patients with ER-positive disease. ${ }^{93-96}$ Additional support for this conclusion comes from a retrospective analysis of the recurrence rate of 3585 patients enrolled in 7 ECOG trials of patients treated for nonmetastatic breast cancer, although this data set includes patients undergoing adjuvant therapy. In that study, the annual hazard rate of recurrence was initially lower for patients with ER-positive disease after surgery compared with those with ER-positive disease, but this trend was reversed at approximately year 4 (see Figure 5). ${ }^{97}$

One explanation for the long-term observations represented in Figure 5 is that the population of patients with ER-negative disease is heterogeneous so that only some patients with ER-negative disease have a higher rate of recurrence and death in the first few years after diagnosis. Thus, a "good prognosis" group with ER-negative disease remains recurrencefree over a long-term period. Furthermore, this study suggests that a diagnosis of ER-positive disease is not necessarily a marker of favorable long-term prognosis.

Another study found no differences in outcome with different amounts of ER in early-stage, nodenegative, ER-positive patients with breast cancer not undergoing adjuvant therapy. This suggests that ER may be a weak prognostic factor. ${ }^{91}$ It has also been proposed that ER may not be an independent predictor of outcome but, instead, may be associated with other clinicopathologic features, such as tumor grade or proliferation rate ${ }^{91}$ with ER-positive tumors more likely than ER-negative tumors to be lowergrade $^{13,60,95,98}$ (see Table 3).

Gene expression profiling involving cDNA microarray analyses of several hundred genes showed that breast cancers are biologically and clinically diverse. ${ }^{99,100}$ This type of analysis has been used to identify 5 intrinsic molecular subtypes of breast tumors called luminal A, luminal B, basal, HER2, and normal breast-like. These tumor subtypes are characterized by differences in clinical behavior based on the expression of a large number of genes, with ER-associated genes as key markers in distinguishing 


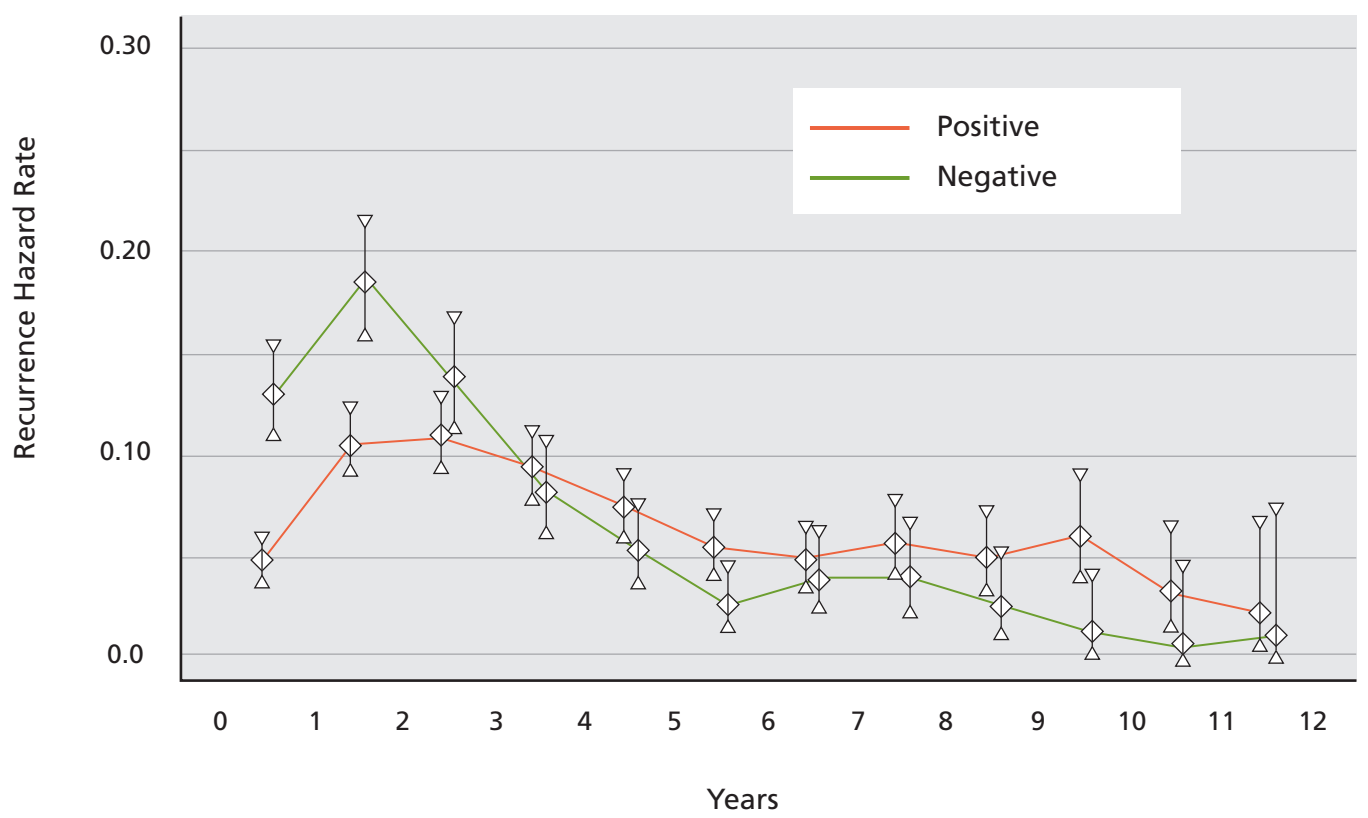

Figure 5 Recurrence rate by estrogen receptor (ER) status. Annual hazard of recurrence of 3562 patients separated by ER status. The mean follow-up times for ER-positive and ER-negative patients were 8.1 and 8.0 years, respectively. (ER status was missing for 23 patients.) From Saphner T, Tormey DC, Gray R. Annual hazard rates of recurrence for breast cancer after primary therapy. J Clin Oncol 1996;14:2738-2746. Reprinted with permission. (c) 2008 American Society of Clinical Oncology. All rights reserved.

the subtypes. ${ }^{101-103}$ For example, the luminal subtypes make up the ER-expressing breast cancers, and tumor proliferation has been identified as a significant discriminator in determining whether an ER-positive tumor is classified as luminal A or B. ${ }^{104,105}$ The luminal A subtype typically has a higher expression of ER-related genes and a lower expression of proliferative genes than the luminal B subtype, and has been associated with a better prognosis, ${ }^{104,106-108}$ ER-negative tumors can be subdivided into HER2, basal, and normal breast tissue subtypes. Although these types of molecular signatures have been shown to be capable of providing powerful prognostic and predictive information, their integration into routine clinical practice is limited by several technical factors and the vast molecular diversity of breast cancer. ${ }^{109,110}$

Recent studies have investigated the ability of small panels of biomarkers evaluated using IHC to act as practical surrogates in the identification of intrinsic tumor subtype in invasive breast cancer $^{104,107,111}$ and DCIS. ${ }^{12-114}$ For example, Livasy et al., ${ }^{111}$ using IHC to measure several tumor markers in invasive breast cancer, identified an IHC-based phenotype of basal-like carcinoma. Nevertheless, the prognostic significance (i.e., information on the aggressiveness of tumors cells regardless of treatment) of these molecular subtypes, based on either gene sets or immunopanels of tumor markers, is still unclear. The benefit of this type of tumor classification may be primarily to provide predictive information on response to particular therapies. ${ }^{107,115}$

ER/PgR as Predictive Factors in Breast Cancer: A predictive factor is defined as a "measurement associated with a response or lack of response to a particular therapy." 70 ER expression as determined by the LB assay, IHC, and RT-PCR has been shown to be a powerful predictor of breast cancer response to endocrine therapy; it is predictive of benefit from tamoxifen in patients with DCIS, ${ }^{116}$ and from tamoxifen and aromatase inhibitors in early-stage and advanced breast cancers. ${ }^{1,3-5,11,12,45,66,70,72,75,117-119}$ Furthermore, endocrine therapy in patients with DCIS or invasive breast cancer has been shown to have no significant benefit if the tumor is ER-and/or PgR-negative. ${ }^{1-5,11,14,45,66,70,72,73,116,119,120}$

Numerous studies have shown that the proportional benefits of tamoxifen vary with the relative quantitative expression of ER. Higher amounts of ER have also been positively correlated with increased clinical response rates and/or improvements in clinical outcome in patients with invasive breast cancer undergoing tamoxifen therapy in the adju- 
Estrogen Receptor and Progesterone Receptor Testing in Breast Cancer

\begin{tabular}{|c|c|c|c|c|}
\hline \multirow[b]{2}{*}{ Tumor Histology } & $E R+/ P g R+(n=98,463)$ & $E R+/ P g R-(n=19,886)$ & $E R-/ P g R+(n=4896)$ & ER-/PgR- $(n=31,930)$ \\
\hline & \multicolumn{4}{|c|}{$(\%)$} \\
\hline Ductal & 62.7 & 12.3 & 3.2 & 21.8 \\
\hline Lobular & 73.6 & 17.7 & 2.3 & 6.4 \\
\hline Ductal/lobular & 76.7 & 13.6 & 2.4 & 7.3 \\
\hline Inflammatory & 37.8 & 13.3 & 6.3 & 42.6 \\
\hline Mucinous & 80.9 & 13.5 & 1.1 & 4.5 \\
\hline Tubular & 79 & 15.2 & 2.1 & 3.7 \\
\hline Comedo & 43.6 & 12.0 & 6.7 & 37.7 \\
\hline Medullary & 14.7 & 8.2 & 5.4 & 71.7 \\
\hline Papillary & 79.0 & 7.9 & 1.3 & 11.8 \\
\hline Other & 49.4 & 12.2 & 3.9 & 34.5 \\
\hline \multicolumn{2}{|l|}{ Tumor Grade } & \multicolumn{2}{|c|}{ (\%) } & \\
\hline 1 & 81.1 & 13.0 & 1.8 & 4.1 \\
\hline 2 & 74.2 & 13.0 & 2.4 & 10.4 \\
\hline 3 & 44.4 & 12.1 & 4.4 & 39.1 \\
\hline 4 & 45.0 & 10.5 & 4.4 & 40.1 \\
\hline
\end{tabular}

Abbreviations: ER, estrogen receptor; PgR, progesterone receptor; SEER, Surveillance, Epidemiology, and End Results.

Adapted from Dunnwald LK, Rossing MA, Li Cl. Hormone receptor status, tumor characteristics, and prognosis: a prospective cohort of breast cancer patients. Breast Cancer Res 2007;9:R6; with permission.

vant setting, ${ }^{1,45,72,121}$ and in the setting of advanced disease. ${ }^{3,4,14,122}$ In addition, increased quantities of ER and/or PgR have also been shown to correlate with a favorable benefit from aromatase inhibitor therapy in women with early-stage hormone receptor-positive breast cancer. ${ }^{45}$

Finally, a retrospective analysis of ER expression in patients with DCIS enrolled in NSABP B-24 suggest that increased levels of expression predict for tamoxifen benefit in terms of risk reduction for the development of both ipsilateral and contralateral breast cancer after breast-conserving therapy. ${ }^{116}$

Whether quantification of ER and tumors markers should be routinely performed in the evaluation of patients with breast cancer is controversial. The National Institutes of Health consensus statement on adjuvant therapy in breast cancer concluded that, "While the likelihood of benefit correlates with the amount of hormone receptor protein in tumor cells, patients with any extent of hormone receptor in their tumor cells may still benefit from hormonal therapy." 123 Likewise, recommendations in the NCCN Clinical Practice Guidelines in Oncology: Breast Cancer (to view the most recent version of these guidelines, visit the NCCN Web site at www.nccn.org) regarding endocrine therapy for particular populations of patients with hormone receptor-positive disease are not contingent on tumor hormone receptor levels. ${ }^{124}$

Tumor hormone receptor levels also seem to impact the effectiveness of cytotoxic chemotherapy. The predicted benefit from chemotherapy in the adjuvant setting has been assessed in several studies of patients with ER-positive tumors undergoing chemotherapy plus tamoxifen compared with those undergoing chemotherapy alone for the treatment of ER-negative breast cancer. ${ }^{1,6}$ These analyses suggest that the benefits of chemotherapy are significantly greater in patients with ER-negative disease, although studies incorporating other tumor markers, such as HER2 and Ki-67, also show that particular tumor subtypes characterized by HER2 and/or Ki-67 overexpression may exhibit chemosensitivity despite being ER-positive. ${ }^{107}$ Furthermore, several studies have shown that the level of tumor ER may help select the subsets of patients with ER-positive disease who are likely to benefit from the addition of chemotherapy to endocrine therapy. ${ }^{5,6,85,125}$

Although the NCCN Breast Cancer Guidelines 
do not include specific recommendations for the evaluation of the quantity of ER and PgR in tumor cells, the Oncotype DX assay (which provides a recurrence score that includes weighted contributions from continuous ER and PgR scores based on the levels of expression of these 2 tumor markers in addition to contributions from 14 other biomarkers) is listed as an option for some patients with ER-positive disease. ${ }^{124}$ Similar to the NCCN guidelines, the 2009 St. Gallen guidelines recommend endocrine therapy for all patients with ER-positive disease regardless of the level of ER. ${ }^{126}$ The 2007 version of the St. Gallen guidelines included a description of 3 categories of endocrine responsiveness: "highly endocrine responsive" (tumors express high levels of both steroid receptors in the majority of cells), "incompletely endocrine responsive" (some expression of steroid hormone receptors but at lower levels or lacking either ER or PgR), and "endocrine nonresponsive disease" (tumors have no detectable expression of steroid hormone receptors). ${ }^{127}$ The most recent version of those guidelines mentions consideration of these categories of endocrine responsiveness in the context of guiding decisions regarding use of chemoendocrine therapy in patients with ER-positive, HER2-negative disease. ${ }^{126}$

\section{Biologic Issues}

ER/PgR Tests: Surrogates of Biologic Processes: The most important purpose of evaluating the ER/ PgR tumor status for individual patients is to predict whether a clinically important benefit from a particular therapy is likely..$^{50,51}$ This would ideally involve a comprehensive assessment of the functionality of ER and PgR, including an evaluation of the activated downstream proteins of these receptors. However, IHC assays of ER and PgR are limited to determining whether these receptors are present in tumor cells and providing some information on the levels of ER and PgR in breast cancer tissue. Although some versions of the Oncotype DX and MammaPrint assays focus on determining a continuous range of values to represent expression of ER and PgR genes (Methods of Detecting ER and PgR in Breast Cancer, page $\mathrm{S}-5)$, these results provide information on steroid receptor mRNA levels only. ${ }^{12,87}$ High-throughput gene expression microarrays have the potential to provide information on the mechanisms behind the development of endocrine resistance and causes of endocrine refractory disease in hormone receptor- positive tumors. Nevertheless, technical issues and the enormous complexity of the molecular impact of estrogen and progesterone on breast cancer tissue limit the integration of these types of assays into routine clinical practice. For example, gene expression profiling analyses of an ER-positive breast cancer cell line have identified more than 800 genes that are regulated by estrogen. ${ }^{88}$

ER Tumor Status: Fixed or Dynamic?: Whether breast cancer tumor hormone receptor phenotype is stable throughout disease progression has been addressed in several studies with variable results. A prospective trial evaluating ER/PgR tumor status in 29 samples from patients with newly suspected metastatic breast cancer and previous sampling of primary tumor showed significant discordances between sample sets (i.e., $40 \%$ of patients had a change in hormone receptor status). ${ }^{128}$ In another study comparing primary tumors and paired metastases from 75 patients with breast cancer, a change in either ER or PgR status was seen in $21 \%$ of cases. ${ }^{129}$ An investigation of 789 patients with metastatic breast cancer showed ER and PgR discordance rates of 18.4\% and $40.3 \%$, respectively, between primary and metastatic disease sites. ${ }^{130}$ Finally, a report from a study that compared tissue from the primary breast cancer tumor with paired axillary lymph node metastases showed a change in tumor status in only approximately $4 \%$ to $6 \%$ of patients. ${ }^{131}$ The stability/mutability of breast cancer hormone receptor status requires further investigation. The 2009 NCCN Breast Cancer Guidelines include a recommendation for a biopsy of first recurrence of disease with determination of ER and PgR receptor status, if possible.

\section{Histologic Subtype/Tumor Grade and Hormone} Receptor Status: Table 3 summarizes data on the association between tumor hormone receptor status and tumor histology for 155,175 women with invasive breast cancer included in the Surveillance, Epidemiology, and End Results (SEER) registry from 1990 to $2001 .{ }^{98}$ One major limitation of registry data such as these is that hormone receptor determinations were made in many different laboratories using various methods and the possibility of misclassifications cannot be excluded. Nonetheless, these data indicate that tubular and mucinous breast cancers are virtually always ER-and/or PR-positive. Table 3 also provides evidence of an association between low tumor grade (i.e., grade 1 and 2) and tumor hormone 
receptor status, showing the occurrence of a grade 1 or 2 tumor with a negative hormone receptor status to be unlikely.

\section{ER/PgR Testing by IHC: Methodologic Issues}

This section discusses the testing techniques and reporting procedures that may impact the results and interpretation of IHC tests of ER and PgR in breast cancer tissue.

Reports have shown interlaboratory variability for ER and PgR testing with IHC. ${ }^{10,132-136}$ Many laboratories performing IHC tests of ER and PgR in breast cancer tissue are using assays that have not been comprehensively validated technically or clinically (see Methods of Detecting ER and PgR in Breast Cancer, page S-5). Multiple sources of variability with IHC testing involve preanalytic, analytic, and postanalytic factors (see Table 4). Some of the variability includes use of diverse methods of preparing tissue; diverse reagents; diverse methods of staining; diverse methods of scoring; arbitrary definitions of "positive;" and inadequate quality control. ${ }^{78,81,137-140}$ For example, considerable variability exists in the monoclonal antibodies used and, most importantly, in the interpretation of results in the context of clinical outcome. ${ }^{52}$ Rigorous standardization, quality control, validation, and quality assurance of the methodologies used to perform these tests are needed.

Preanalytic Factors: Hormone receptor testing can be performed on tissue obtained from a needle core biopsy and/or a breast resection specimen. Variations in the fixation and preparation of breast resection and core biopsy tissue specimens are sources of test variability. IHC tests of ER on matched samples from core biopsies and excisional biopsies have documented good correlation. ${ }^{141}$ Nevertheless, the ER positivity rate was higher in the core biopsy specimens, and the resection specimens showed variable rates of ER positivity according to distance from the tumor edge (higher ER positivity noted at the outer edges of the tissue), suggesting incomplete fixation of the resection samples. More recent studies showed nearly $100 \%$ concordance for IHC tests of ER and PgR using matched specimen samples. ${ }^{142-144}$

Reports have shown that the likelihood of obtaining an ER-negative breast cancer specimen can vary according to the day of surgery. ${ }^{145}$ In this case, overfixation of samples brought to the laboratory on a Friday or Saturday leading to an increased frequen- cy of ER-negative tests caused by antigen lability was suggested as an explanation for this observation. Goldstein et al. ${ }^{146}$ reported that a minimum of 6 to 8 hours of tissue exposure to formalin was needed to obtain consistent and reproducible ER results, irrespective of specimen type. Consistency in the process of embedding the sample in paraffin and sectioning the tissue has also been identified as important to obtaining reproducible results (see Table 1). ${ }^{138}$

Analytic Factors: Many analytic factors can influence the determination of tumor ER and PgR status in breast cancer tissue as measured using IHC methods. Of paramount importance is the level of training and competency of the laboratory staff. ${ }^{52,137}$ The sensitivity of the assay has also been repeatedly identified as being particularly significant, because inadequate sensitivity can cause weak staining and increase the likelihood of a false-negative result. The

Table 4 Sources of Marker Testing Variation

Preanalytic

- Time to fixation

- Method of tissue processing

- Time of fixation

- Type of fixation

Analytic

- Assay validation

- Equipment calibration

- Use of standardized laboratory procedures

- Training and competency assessment of staff

- Type of antigen retrieval

- Test reagents

- Use of standardized control materials

- Use of automated laboratory methods

Postanalytic

- Interpretation criteria

- Use of image analysis

- Reporting elements

- Quality assurance procedures

o Laboratory accreditation

o Proficiency testing

o Pathologist competency assessment

From Wolff AC, Hammond ME, Schwartz JN, et al. American Society of Clinical Oncology/College of American Pathologists guideline recommendations for human epidermal growth factor receptor 2 testing in breast cancer. J Clin Oncol 2007;25:118-145. Reprinted with permission. C2008 American Society of Clinical Oncology. All rights reserved. 
sensitivity of the IHC assay should be appropriate to capture the full dynamic range of expression. Analytic factors contributing to assay sensitivity include the quality of tissue fixation; quality and concentration of the primary antibody; antigen retrieval procedure used; and staining and detection processes. ${ }^{133,147}$ Antibody Issues: Numerous monoclonal antibodies are available against ER and PgR, although most of these have not been validated clinically. ${ }^{143}$ Furthermore, not all of these antibodies are very sensitive and specific for detecting ER and PgR. The following antibodies against ER have been well characterized as being suitable for clinical use: $6 \mathrm{~F} 11^{66} 1 \mathrm{D} 5,,^{11,45,67,148}$ SP1, ${ }^{72}$ and the cocktail of ER.2.123 plus 1D5.78 Likewise, IHC tests using the 1294, 1A6, and 312 antibodies against $\mathrm{PgR}$, which react with both isoforms of PgR, have been shown to be equivalent or superior to the LB assay with respect to predicting clinical outcome. . $^{45,69,70}$

Antigen retrieval involves sample heating, which is believed to disrupt some of the protein crosslinks induced by formalin fixation and to restore immunoreactivity; ${ }^{149}$ it is an important component in the optimization of assay sensitivity (see Table 1 ). Rhodes et al. ${ }^{133}$ found that inadequate antigen retrieval contributed substantially to a lowering of the sensitivity of IHC for detecting ER and PgR, and this conclusion has been supported in several studies. ${ }^{63,78,137}$

Quality Control: Reference materials, serving as both negative and positive controls, and subject to the same fixation, processing, and testing conditions as used for the test sample, are necessary to standardize and calibrate results of a test. ${ }^{137,138}$ Two types of controls are used: batch controls and biologic internal controls. All IHC analyses must include both a positive and negative control for each batch run. The test sample itself may not have an internal positive control but will almost always have an internal negative control (e.g., endothelial cells, lymphocytes). Traditionally, normal, nonneoplastic breast tissue embedded within the same block as the tumor tissue has been used as an internal positive control. ${ }^{139}$ External controls include endomyometrial and cervical tissue (i.e., as positive controls) and pellets of cultured cells embedded within paraffin blocks (i.e., Quicgel system). ${ }^{78,139,150}$ These cell lines can be either ER- and PgR-positive (i.e., positive controls) or ER- and PgR-negative (i.e., negative controls). The assay should also include a negative control reagent (i.e., substitution of a nonspecific, or nonsense, primary antibody for the hormone receptor-specific monoclonal antibody in the assay). ${ }^{63}$

Synthetic peptides with primary sequences corresponding to the ER and $\mathrm{PgR}$ epitopes recognized by various monoclonal antibodies used for IHC testing are another potential source of reference material. ${ }^{143,151-154}$ Specific concentrations of these peptides are attached to isocyanate-activated slides. This is a promising source of standard/control material for IHC testing of ER and PgR, although additional studies are needed to further characterize this technology. Detection Systems/Staining Issues: Classic IHC assays of ER and PgR of breast cancer tissue involve deposition of a chromogenic stain at the binding sites of monoclonal antibodies targeted to these hormone receptors (Table 1 and Figure 3). However, the relationship between the actual concentration of a particular hormone receptor in the tissue and the amount of the receptor protein detected through the IHC staining process is complex, and may be influenced by the tissue fixation process (see Preanalytic Factors, page S-13) and sensitivity of the assay. ${ }^{155}$ For example, highly sensitive IHC assays increase the proportion and intensity of cells stained compared with less-sensitive IHC assays performed on the same tissue, and the relationship between levels of hormone receptors determined using an enzyme immunoassay is not linearly correlated with hormone receptor level in a highly sensitive IHC assay. ${ }^{155,156}$

Whether the chromogenic stain used in these assays has sufficient dynamic range for capturing and quantifying the broad spectrum of hormone receptor concentrations found in breast cancer tissue is a subject of debate. ${ }^{81}$ However, use of stain intensity in addition to the extent of staining to score IHC test results may facilitate interpretation of slides with low levels of ER expression. The intensity of hormone receptor immunostaining can be assessed visually or through computerized image analysis. ${ }^{65}$ Although the latter method provides a more accurate assessment of stain intensity, it is limited with respect to several factors, such as its ability to precisely distinguish between benign and malignant lesions. ${ }^{65}$

Technical and Clinical Validation: Each laboratory performing IHC assays of ER and PgR must show that those assays are technically valid (see Methods of Detecting ER and PgR in Breast Cancer, page S-5). This requirement exists despite whether the assay in use is FDA-approved. A laboratory can accomplish 
technical validation of an assay in 2 ways: external validation using a "split sample" technique (i.e., performing a concordance study of assay results obtained on a set of samples in that laboratory, with results obtained on the same sample set in another laboratory known to have a technically valid assay [i.e., an "expert laboratory"]) or internal validation using a set of standard samples provided by an organization such as the College of American Pathologists (CAP) or National Institute of Standards and Technology (NIST), with established ER and PgR status determined through IHC testing using a technically validated assay. Clinical validation of an assay can be inferred if the technically validated reference assay is one that has been shown to be clinically valid (see Table 2). ${ }^{78}$ Alternatively, clinical validation can be inferred if high concordance is seen between results obtained on the standard set of samples and the original determination of $\mathrm{ER} / \mathrm{PgR}$ status of those samples was performed using a clinically valid assay (see Table 2).

Postanalytic Factors: Interpretation of Results: Interpretive variables in IHC testing include the scoring system used and established cutoff value distinguishing a positive from a negative result. Numerous systems have been used to score IHC test results for ER and PgR in breast tissue, including a strictly dichotomous assessment (i.e., positive vs. negative), ${ }^{13}$ and more quantitative systems such as those based on proportion of cells stained only, and scoring systems that include both the proportion of cells stained and the intensity of the staining (see Methods of Detecting ER and PgR in Breast Cancer, page S-5). ${ }^{10,45,52,66,68,70}$

Ideally, the cutoff value used in clinical practice should be calibrated to clinical outcome. ${ }^{47,52} \mathrm{~A}$ wide range of cutoff values have been used to interpret results of IHC assays of hormone receptors (e.g., 1\%, $5 \%$, and $10 \%$ of tumor cells), although most have not been clinically validated. Although cutoff values distinguishing a positive from a negative result cannot be assumed to be transferable from one assay method to another, studies of most well-validated IHC assays have shown that very low levels of proportion of cells stained ( $\geq 1 \%$ of cells) are clinically important (see Table 2).

Controversy continues as to whether quantification of ER and PgR beyond a dichotomous "positive" or "negative" is warranted. In 2 recent studies of more than 7000 samples combined, a bimodal dis- tribution of ER values (i.e., completely ER-negative or strongly ER-positive) was observed in more than $90 \%$ of the samples using contemporary IHC methodology. ${ }^{13,63,155}$ Alternatively, the possibility that future drugs may benefit only patients with high levels of ER expression provides some support for quantifying IHC test results. ${ }^{143}$ Whether in fact measuring stain intensity in IHC assays of hormone receptors has any clinical significance is another topic of debate. ${ }^{137}$ However, some evidence indicates that accounting for both proportion and intensity parameters may provide a test score that correlates more closely with clinical outcome. ${ }^{70}$

Reporting of Results: Reports of IHC test results of breast cancer tumor ER and PgR status must provide sufficient information for informed clinicians to effectively use the results in clinical decision making. For example, the time of tumor fixation, type of fixative, and primary antibody used should be included in the report. Alternatively, information regarding the details of the specific assay used can be summarized in detail in laboratory standard operating procedures and referenced in the report. Other important information includes a clear statement of the ER and PgR status of the tumor (i.e., positive or negative) and the criteria used to determine the status (see Methodologic Recommendations, page S-16), and how the results were quantified. ASCO/ CAP guidelines should be consulted for more detailed information regarding elements of the report. Clinicians responsible for evaluating tests of ER and PgR should be familiar with these criteria and their clinical ramifications.

External Quality Assurance: Laboratory quality assurance programs are based on the principles of external monitoring and enforcement. Ongoing evaluations by external agencies (e.g., CAP) of IHC testing proficiency and external reviews of laboratory documentation on the competency of the pathologists determining the ER and PgR status of breast cancer tumors are key components of these programs. Laboratory accreditation by CAP will be based on results of these ongoing evaluations (see ASCO/CAP guidelines).

\section{Task Force Recommendations}

The recommendations of the task force are summarized in Figure 6. 


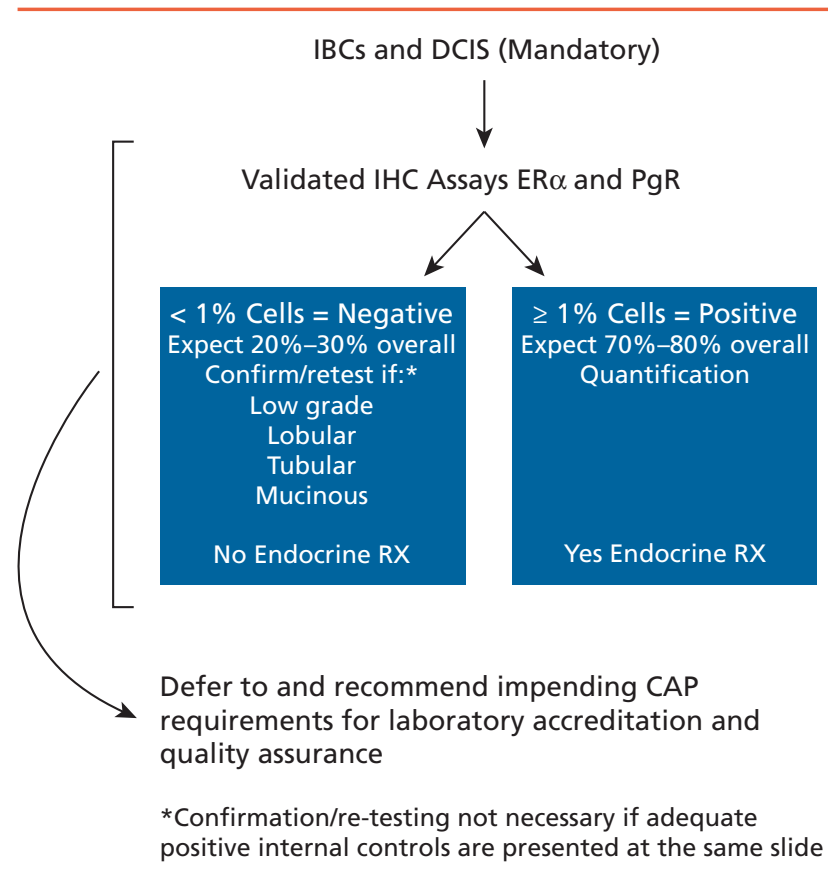

Figure 6 IHC testing algorithm.

\section{Clinical Recommendations}

- Both ER and PgR status should be determined for all invasive breast cancers and DCIS.

- If a core biopsy is negative for $\mathrm{ER} / \mathrm{PgR}$, and without internal controls that are positive (i.e., nonneoplastic tissue), testing should be repeated on the excisional specimen.

- ER- and PgR-negative tumor status should be retested if tumor histology is lobular, tubular, or mucinous, because these types of tumors are rarely negative, and confirmation of histologic diagnosis should be performed. An exception to the need for confirmation/retesting is when adequate positive internal controls are present on the same slide.

- ER- and PgR-negative tumor status should be retested if tumor grade is 1 because these tumors are rarely negative. An exception to the need for confirmation/retesting is when adequate positive internal controls are present on the same slide.

- ER/PgR testing should be performed at primary diagnosis and first relapse.

- The option of endocrine therapy for patients with tumors characterized by ER - and/or PgRpositive status does not depend on level of hormone receptor expression.

\section{Methodologic Recommendations}

- Priority should be given to improve the quality of IHC testing and testing methodologies.

- IHC tests of ER and PgR should not be restricted to those that are FDA-approved.

- All assays of ER and PgR, including preanalytic processes, must be technically validated with a demonstrated 95\% concordance with another technically validated assay.

- Technical validation should be performed on samples representative of those typically tested in the laboratory

- All assays of ER and PgR must be clinically validated. This can be accomplished by technically validating an assay against one that is technically and clinically validated (as listed in Table 2) or by technically validating an assay which has been shown to be clinically validated (as listed in Table 2).

- Tissue fixation in $10 \%$ neutral buffered formalin fixative for 12 to 48 hours is recommended.

- All IHC analyses must include both a positive and a negative control for each batch run.

- Antibodies recommended for IHC testing of ER include ID5, 6F11, SP1, or ER.2.123 + 1D5 (cocktail).

- Antibodies recommended for IHC testing of PgR include 1294, 1A6, or 312.

- A cutoff value of $1 \%$ (i.e., $<1 \%$ is negative; $\geq$ $1 \%$ is positive) is recommended to distinguish a positive from a negative result when interpreting an IHC test of ER or PgR tumor status.

- Hormone receptor quantification should be maintained when scoring IHC assays of ER and PgR. This includes evaluation of both proportion/percentage of cells stained and stain intensity using one of several acceptable, validated methods, including $\mathrm{H}$-score, Allred score, computer image analysis, absolute counting, or point counting. An additional evaluation of stain intensity should also be performed if either absolute counting or point counting scoring methods are used.

- The test report should document information on tumor characteristics, tissue handling, testing processes, and laboratory procedures. It should also provide informed clinicians with the information necessary for effective clinical decision making. Guidelines from ASCO and CAP to be published in the near future will provide comprehensive information regarding essential ele- 
Estrogen Receptor and Progesterone Receptor Testing in Breast Cancer

ments to include in the test report.

- Laboratories should meet ongoing requirements of quality assurance parameters specified in the ASCO/CAP guidelines that will be published in the near future.

\section{Conclusions}

Measurements of ER, and to a lesser extent PgR, provide crucial information in the treatment planning of patients with breast cancer. Currently, almost all testing of these hormone receptors is performed using IHC, and this methodology is expected to continue to be the main testing strategy for evaluating hormone receptor status in breast cancer for some time. Nevertheless, a high false-negative rate has been associated with this type of testing when laboratory quality control and assurance measures are inadequate. All laboratories performing breast cancer hormone receptor testing using IHC must ensure pathologic expertise of laboratory personnel, demonstrate both technical and clinical validation of the standardized IHC assay being used, keep comprehensive records, provide complete test reports, and meet ongoing quality assurance and proficiency testing requirements.

\section{References}

1. Early Breast Cancer Trialists' Collaborative Group. Effects of chemotherapy and hormonal therapy for early breast cancer on recurrence and 15-year survival: an overview of the randomised trials. Lancet 2005;365:1687-1717.

2. Clarke M, Coates AS, Darby SC, et al. Adjuvant chemotherapy in oestrogen-receptor-poor breast cancer: patient-level metaanalysis of randomised trials. Lancet 2008;371:29-40.

3. Manni A, Arafah B, Pearson OH. Estrogen and progesterone receptors in the prediction of response of breast cancer to endocrine therapy. Cancer 1980;46(12 Suppl):2838-2841.

4. Osborne CK, Yochmowitz MG, Knight WA III, McGuire WL. The value of estrogen and progesterone receptors in the treatment of breast cancer. Cancer 1980;46(12 Suppl):2884-2888.

5. Viale G, Regan MM, Maiorano E, et al. Chemoendocrine compared with endocrine adjuvant therapies for node-negative breast cancer: predictive value of centrally reviewed expression of estrogen and progesterone receptors-International Breast Cancer Study Group. J Clin Oncol 2008;26:1404-1410.

6. Berry DA, Cirrincione C, Henderson IC, et al. Estrogen-receptor status and outcomes of modern chemotherapy for patients with node-positive breast cancer. JAMA 2006;295:1658-1667.

7. Hede K. Breast cancer testing scandal shines spotlight on black box of clinical laboratory testing. J Natl Cancer Inst 2008;100:836-837, 844 .
8. Allred DC. Commentary: hormone receptor testing in breast cancer: a distress signal from Canada. Oncologist 2008;13:11341136.

9. CBC News. Quebec re-examining breast cancer study. Available at: http://www.cbc.ca/health/story/2009/05/30/breast-cancerquebec.html Accessed August 2, 2009.

10. Rhodes A, Jasani B, Barnes DM, et al. Reliability of immunohistochemical demonstration of oestrogen receptors in routine practice: interlaboratory variance in the sensitivity of detection and evaluation of scoring systems. J Clin Pathol 2000;53:125-130.

11. Viale G, Regan MM, Maiorano E, et al. Prognostic and predictive value of centrally reviewed expression of estrogen and progesterone receptors in a randomized trial comparing letrozole and tamoxifen adjuvant therapy for postmenopausal early breast cancer: BIG 1-98. J Clin Oncol 2007;25:3846-3852.

12. Badve SS, Baehner FL, Gray RP, et al. Estrogen- and progesterone-receptor status in ECOG 2197: comparison of immunohistochemistry by local and central laboratories and quantitative reverse transcription polymerase chain reaction by central laboratory. J Clin Oncol 2008;26:2473-2481.

13. Nadji M, Gomez-Fernandez C, Ganjei-Azar P, Morales AR. Immunohistochemistry of estrogen and progesterone receptors reconsidered: experience with 5,993 breast cancers. Am J Clin Pathol 2005;123:21-27.

14. Elledge RM, Green S, Pugh R, et al. Estrogen receptor (ER) and progesterone receptor $(\mathrm{PgR})$, by $\mathrm{LB}$ assay compared with ER, $\mathrm{PgR}$ and $\mathrm{pS} 2$, by immuno-histochemistry in predicting response to tamoxifen in metastatic breast cancer: a Southwest Oncology Group study. Int J Cancer 2000;89:111-117.

15. Rhodes A, Jasani B, Balaton AJ, et al. Frequency of oestrogen and progesterone receptor positivity by immunohistochemistry analysis in 7016 breast carcinomas: correlation with patient age, assay sensitivity, threshold value, and mammographic screening. J Clin Oncol 2009;53:688-696.

16. Winn RJ, McClure JS. About the NCCN Clinical Practice Guidelines in Oncology. Available at: http://www.nccn.org/ professionals/physician_gls/about.asp Accessed August 2, 2009.

17. Jensen EV. On the mechanism of estrogen action. Perspect Biol Med 1962;6:47-59.

18. Jensen EV, Jordan VC. The estrogen receptor: a model for molecular medicine. Clin Cancer Res 2003;9:1980-1989.

19. Greene GL, Press MF. Structure and dynamics of the estrogen receptor. J Steroid Biochem 1986;24:1-7.

20. Kuiper GG, Enmark E, Pelto-Huikko M, et al. Cloning of a novel receptor expressed in rat prostate and ovary. Proc Natl Acad Sci U S A 1996;93:5925-5930.

21. Kuiper GG, Carlsson B, Grandien K, et al. Comparison of the ligand binding specificity and transcript tissue distribution of estrogen receptors alpha and beta. Endocrinology 1997;138:863870.

22. Enmark E, Pelto-Huikko M, Grandien K, et al. Human estrogen receptor beta-gene structure, chromosomal localization, and expression pattern. J Clin Endocrinol Metab 1997;82:4258-4265.

23. Horwitz KB, Alexander PS. In situ photolinked nuclear progesterone receptors of human breast cancer cells: subunit molecular weights after transformation and translocation. Endocrinology 1983;113:2195-2201.

24. Kastner P, Krust A, Turcotte B, et al. Two distinct estrogenregulated promoters generate transcripts encoding the two 
functionally different human progesterone receptor forms A and B. J Embo 1990;9:1603-1614.

25. Ellmann S, Sticht H, Thiel F, et al. Estrogen and progesterone receptors: from molecular structures to clinical targets. Cell Mol Life Sci 2009;66:2405-2426.

26. Tanenbaum DM, Wang Y, Williams SP, Sigler PB. Crystallographic comparison of the estrogen and progesterone receptor's ligand binding domains. Proc Natl Acad Sci U S A 1998;95:5998-6003.

27. Figtree GA, McDonald D, Watkins H, Channon KM. Truncated estrogen receptor alpha $46-\mathrm{kDa}$ isoform in human endothelial cells: relationship to acute activation of nitric oxide synthase. Circulation 2003;107:120-126.

28. Poola I, Speirs V. Expression of alternatively spliced estrogen receptor alpha mRNAs is increased in breast cancer tissues. J Steroid Biochem Mol Biol 2001;78:459-469.

29. Fasco MJ, Keyomarsi K, Arcaro KF, Gierthy JF. Expression of an estrogen receptor alpha variant protein in cell lines and tumors. Mol Cell Endocrinol 2000;166:156-169.

30. Pedram A, Razandi M, Levin ER. Nature of functional estrogen receptors at the plasma membrane. Mol Endocrinol 2006;20:19962009.

31. Schlegel A, Wang C, Katzenellenbogen BS, et al. Caveolin-1 potentiates estrogen receptor alpha (ERalpha) signaling. caveolin-1 drives ligand-independent nuclear translocation and activation of ERalpha. J Biol Chem 1999;274:33551-33556.

32. Pedram A, Razandi M, Sainson RC, et al. A conserved mechanism for steroid receptor translocation to the plasma membrane. J Biol Chem 2007;282:22278-22288.

33. Norman AW, Mizwicki MT, Norman DP. Steroid-hormone rapid actions, membrane receptors and a conformational ensemble model. Nat Rev Drug Discov 2004;3:27-41.

34. Levin ER, Pietras RJ. Estrogen receptors outside the nucleus in breast cancer. Breast Cancer Res Treat 2008;108:351-361.

35. Likhite VS, Stossi F, Kim K, et al. Kinase-specific phosphorylation of the estrogen receptor changes receptor interactions with ligand, deoxyribonucleic acid, and coregulators associated with alterations in estrogen and tamoxifen activity. Mol Endocrinol 2006;20:3120-3132.

36. Mintz PJ, Habib NA, Jones LJ, et al. The phosphorylated membrane estrogen receptor and cytoplasmic signaling and apoptosis proteins in human breast cancer. Cancer 2008;113:1489-1495.

37. Giordano C, Cui Y, Barone I, et al. Growth factor-induced resistance to tamoxifen is associated with a mutation of estrogen receptor alpha and its phosphorylation at serine 305. Breast Cancer Res Treat 2009; in press.

38. Wijayaratne AL, McDonnell DP. The human estrogen receptoralpha is a ubiquitinated protein whose stability is affected differentially by agonists, antagonists, and selective estrogen receptor modulators. J Biol Chem 2001;276:35684-35692.

39. Jordan VC, O'Malley BW. Selective estrogen-receptor modulators and antihormonal resistance in breast cancer. J Clin Oncol 2007;25:5815-5824.

40. McClelland RA, Manning DL, Gee JM, et al. Effects of shortterm antiestrogen treatment of primary breast cancer on estrogen receptor mRNA and protein expression and on estrogen-regulated genes. Breast Cancer Res Treat 1996;41:31-41.

41. Pietras RJ. Biologic basis of sequential and combination therapies for hormone-responsive breast cancer. Oncologist 2006;11:704717.
42. Miller WR, Bartlett J, Brodie AM, et al. Aromatase inhibitors: are there differences between steroidal and nonsteroidal aromatase inhibitors and do they matter? Oncologist 2008;13:829-837.

43. Normanno N, Di Maio M, De Maio E, et al. Mechanisms of endocrine resistance and novel therapeutic strategies in breast cancer. Endocr Relat Cancer 2005;12:721-747.

44. Generali D, Buffa FM, Berruti A, et al. Phosphorylated ERalpha, HIF-1alpha, and MAPK signaling as predictors of primary endocrine treatment response and resistance in patients with breast cancer. J Clin Oncol 2009;27:227-234.

45. Dowsett M, Allred C, Knox J, et al. Relationship between quantitative estrogen and progesterone receptor expression and human epidermal growth factor receptor 2 (HER-2) status with recurrence in the Arimidex, Tamoxifen, Alone or in Combination trial. J Clin Oncol 2008;26:1059-1065.

46. Pietras RJ, Arboleda J, Reese DM, et al. HER-2 tyrosine kinase pathway targets estrogen receptor and promotes hormoneindependent growth in human breast cancer cells. Oncogene 1995;10:2435-2446.

47. McGuire WL. Breast cancer prognostic factors: evaluation guidelines. J Natl Cancer Inst 1991;83:154-155.

48. Burke HB, Henson DE. The American Joint Committee on Cancer. Criteria for prognostic factors and for an enhanced prognostic system. Cancer 1993;72:3131-3135.

49. Henson DE, Fielding LP, Grignon DJ, et al. College of American Pathologists Conference XXVI on clinical relevance of prognostic markers in solid tumors. Summary. Members of the Cancer Committee. Arch Pathol Lab Med 1995;119:1109-1112.

50. Hayes DF, Bast RC, Desch CE, et al. Tumor marker utility grading system: a framework to evaluate clinical utility of tumor markers. J Natl Cancer Inst 1996;88:1456-1466.

51. Harris L, Fritsche H, Mennel R, et al. American Society of Clinical Oncology 2007 update of recommendations for the use of tumor markers in breast cancer. J Clin Oncol 2007;25:5287-5312.

52. Allred DC, Harvey JM, Berardo M, Clark GM. Prognostic and predictive factors in breast cancer by immunohistochemical analysis. Mod Pathol 1998;11:155-168.

53. Graham JD, Roman SD, McGowan E, et al. Preferential stimulation of human progesterone receptor B expression by estrogen in T-47D human breast cancer cells. J Biol Chem 1995;270:30693-30700.

54. Wei LL, Krett NL, Francis MD, et al. Multiple human progesterone receptor messenger ribonucleic acids and their autoregulation by progestin agonists and antagonists in breast cancer cells. Mol Endocrinol 1988;2:62-72.

55. McGuire WL. Estrogen receptors in human breast cancer. J Clin Invest 1973;52:73-77.

56. Clark GM. Prognostic and predictive factors. In: Harris J, Lippman ME, Morrow M, Hellman S, eds. Diseases of the Breast. Philadelphia: Lippincott-Raven; 1996:461-485.

57. Osborne CK. Receptors. In: Harris JR, Hellman S, Henderson JC, eds. Philadelphia: Lippincott; 1991:310-325.

58. McCarty KS Jr, Miller LS, Cox EB, et al. Estrogen receptor analyses. Correlation of biochemical and immunohistochemical methods using monoclonal antireceptor antibodies. Arch Pathol Lab Med 1985;109:716-721.

59. McCarty KS Jr, Szabo E, Flowers JL, et al. Use of a monoclonal anti-estrogen receptor antibody in the immunohistochemical evaluation of human tumors. Cancer Res 1986;46(Suppl 8):4244s-4248s. 
60. Magne N, Toillon RA, Castadot P, et al. Different clinical impact of estradiol receptor determination according to the analytical method: a study on 1940 breast cancer patients over a period of 16 consecutive years. Breast Cancer Res Treat 2006;95:179-184.

61. Budwit-Novotny DA, McCarty KS, Cox EB, et al. Immunohistochemical analyses of estrogen receptor in endometrial adenocarcinoma using a monoclonal antibody. Cancer Res 1986;46:5419-5425.

62. Dowsett M. Overexpression of HER-2 as a resistance mechanism to hormonal therapy for breast cancer. Endocr Relat Cancer 2001;8:191-195.

63. Collins LC, Botero ML, Schnitt SJ. Bimodal frequency distribution of estrogen receptor immunohistochemical staining results in breast cancer: an analysis of 825 cases. Am J Clin Pathol 2005;123:16-20.

64. Fisher ER, Anderson S, Dean S, et al. Solving the dilemma of the immunohistochemical and other methods used for scoring estrogen receptor and progesterone receptor in patients with invasive breast carcinoma. Cancer 2005;103:164-173.

65. Turbin DA, Leung S, Cheang MC, et al. Automated quantitative analysis of estrogen receptor expression in breast carcinoma does not differ from expert pathologist scoring: a tissue microarray study of 3484 cases. Breast Cancer Res Treat 2008;110:417-426.

66. Harvey JM, Clark GM, Osborne CK, Allred DC. Estrogen receptor status by immunohistochemistry is superior to the ligand-binding assay for predicting response to adjuvant endocrine therapy in breast cancer. J Clin Oncol 1999;17:1474-1481.

67. Barnes DM, Harris WH, Smith P, et al. Immunohistochemical determination of oestrogen receptor: comparison of different methods of assessment of staining and correlation with clinical outcome of breast cancer patients. Br J Cancer 1996;74:14451451.

68. Wilbur DC, Willis J, Mooney RA, et al. Estrogen and progesterone receptor detection in archival formalin-fixed, paraffin-embedded tissue from breast carcinoma: a comparison of immunohistochemistry with the dextran-coated charcoal assay. Mod Pathol 1992;5:79-84.

69. Regan MM, Viale G, Mastropasqua MG, et al. Re-evaluating adjuvant breast cancer trials: assessing hormone receptor status by immunohistochemical versus extraction assays. J Natl Cancer Inst 2006;98:1571-1581.

70. Mohsin SK, Weiss H, Havighurst T, et al. Progesterone receptor by immunohistochemistry and clinical outcome in breast cancer: a validation study. Mod Pathol 2004;17:1545-1554.

71. Allred DC, Mohsin SK. The assessment of hormone receptors in breast cancer by immunohistochemistry. Semin Breast Dis 2005;8:57-61.

72. Cheang MC, Treaba DO, Speers $\mathrm{CH}$, et al. Immunohistochemical detection using the new rabbit monoclonal antibody SP1 of estrogen receptor in breast cancer is superior to mouse monoclonal antibody 1D5 in predicting survival. J Clin Oncol 2006;24:56375644.

73. Love RR, Duc NB, Allred DC, et al. Oophorectomy and tamoxifen adjuvant therapy in premenopausal Vietnamese and Chinese women with operable breast cancer. J Clin Oncol 2002;20:2559_ 2566.

74. Ellis MJ, Tao Y, Luo J, et al. Outcome prediction for estrogen receptor-positive breast cancer based on postneoadjuvant endocrine therapy tumor characteristics. J Natl Cancer Inst 2008;100:1380-1388.
75. Horiguchi J, Koibuchi Y, Iijima K, et al. Co-expressed type of ER and HER2 protein as a predictive factor in determining resistance to antiestrogen therapy in patients with ER-positive and HER2positive breast cancer. Oncol Rep 2005;14:1109-1116.

76. Arpino G, Green SJ, Allred DC, et al. HER-2 amplification, HER-1 expression, and tamoxifen response in estrogen receptorpositive metastatic breast cancer: a Southwest Oncology Group study. Clin Cancer Res 2004;10:5670-5676.

77. ER/PR pharm DX ${ }^{\mathrm{TM}}$ kit [Package Insert]. Carpinteria, CA: Dako Corp, 2008.

78. Phillips T, Murray G, Wakamiya K, et al. Development of standard estrogen and progesterone receptor immunohistochemical assays for selection of patients for antihormonal therapy. Appl Immunohistochem Mol Morphol 2007;15:325-331.

79. Chung GG, Zerkowski MP, Ghosh S, et al. Quantitative analysis of estrogen receptor heterogeneity in breast cancer. Lab Invest 2007;87:662-669.

80. Rimm DL, Giltnane JM, Moeder C, et al. Bimodal population or pathologist artifact? J Clin Oncol 2007;25:2487-2488.

81. McCabe A, Dolled-Filhart M, Camp RL, Rimm DL. Automated quantitative analysis (AQUA) of in situ protein expression, antibody concentration, and prognosis. J Natl Cancer Inst 2005;97:1808-1815.

82. Cregger M, Berger AJ, Rimm DL. Immunohistochemistry and quantitative analysis of protein expression. Arch Pathol Lab Med 2006;130:1026-1030.

83. Mina L, Soule SE, Badve S, et al. Predicting response to primary chemotherapy: gene expression profiling of paraffin-embedded core biopsy tissue. Breast Cancer Res Treat 2007;103:197-208.

84. Paik S, Shak S, Tang G, et al. A multigene assay to predict recurrence of tamoxifen-treated, node-negative breast cancer. $\mathrm{N}$ Engl J Med 2004;351:2817-2826.

85. Paik S, Tang G, Shak S, et al. Gene expression and benefit of chemotherapy in women with node-negative, estrogen receptorpositive breast cancer. J Clin Oncol 2006;24:3726-3734.

86. Allred DC. Problems and solutions in the evaluation of hormone receptors in breast cancer. J Clin Oncol 2008;26:2433-2435.

87. Roepman P, Horlings HM, Krijgsman O, et al. Microarraybased readout of ER, PR, and HER2 expression in breast cancer tissue [abstract]. Presented at the 2008 ASCO Breast Cancer Symposium; September 5-7, 2008; Washington, DC. Abstract 33.

88. Oh DS, Troester MA, Usary J, et al. Estrogen-regulated genes predict survival in hormone receptor-positive breast cancers. J Clin Oncol 2006;24:1656-1664.

89. Rakha EA, El-Sayed ME, Reis-Filho JS, Ellis IO. Expression profiling technology: its contribution to our understanding of breast cancer. Histopathology 2008;52:67-81.

90. Knight WA, Livingston RB, Gregory EJ, McGuire WL. Estrogen receptor as an independent prognostic factor for early recurrence in breast cancer. Cancer Res 1977;37:4669-4671.

91. Fisher B, Redmond C, Fisher ER, Caplan R. Relative worth of estrogen or progesterone receptor and pathologic characteristics of differentiation as indicators of prognosis in node negative breast cancer patients: findings from National Surgical Adjuvant Breast and Bowel Project protocol B-06. J Clin Oncol 1988;6:10761087.

92. Bardou VJ, Arpino G, Elledge RM, et al. Progesterone receptor status significantly improves outcome prediction over estrogen receptor status alone for adjuvant endocrine therapy in two large breast cancer databases. J Clin Oncol 2003;21:1973-1979. 
93. Aamdal S, Bormer O, Jorgensen $O$, et al. Estrogen receptors and long-term prognosis in breast cancer. Cancer 1984;53:2525-2529.

94. Hilsenbeck SG, Ravdin PM, de Moor CA, et al. Time-dependence of hazard ratios for prognostic factors in primary breast cancer. Breast Cancer Res Treat 1998;52:227-237.

95. Pichon MF, Broet $\mathrm{P}$, Magdelenat $\mathrm{H}$, et al. Prognostic value of steroid receptors after long-term follow-up of 2257 operable breast cancers. Br J Cancer 1996;73:1545-1551.

96. Hahnel R, Woodings T, Vivian AB. Prognostic value of estrogen receptors in primary breast cancer. Cancer 1979;44:671-675.

97. Saphner T, Tormey DC, Gray R. Annual hazard rates of recurrence for breast cancer after primary therapy. J Clin Oncol 1996;14:2738-2746.

98. Dunnwald LK, Rossing MA, Li CI. Hormone receptor status, tumor characteristics, and prognosis: a prospective cohort of breast cancer patients. Breast Cancer Res 2007;9:R6.

99. Sorlie T, Perou CM, Tibshirani R, et al. Gene expression patterns of breast carcinomas distinguish tumor subclasses with clinical implications. Proc Natl Acad Sci U S A 2001;98:10869-10874.

100. Sorlie T, Tibshirani R, Parker J, et al. Repeated observation of breast tumor subtypes in independent gene expression data sets. Proc Natl Acad Sci U S A 2003;100:8418-8423.

101. Brenton JD, Carey LA, Ahmed AA, Caldas C. Molecular classification and molecular forecasting of breast cancer: ready for clinical application? J Clin Oncol 2005;23:7350-7360.

102. Dawood S, Collins LC, Connolly JL, et al. Defining breast cancer prognosis based on molecular phenotypes: results from a large cohort study [abstract]. Presented at the San Antonio Breast Cancer Symposium; December 10-14, 2008; San Antonio, Texas. Abstract 1068.

103. Parker RL, Huntsman DG, Lesack DW, et al. Assessment of interlaboratory variation in the immunohistochemical determination of estrogen receptor status using a breast cancer tissue microarray. Am J Clin Pathol 2002;117:723-728.

104. Cheang MC, Chia SK, Voduc D, et al. Ki67 index, HER2 status, and prognosis of patients with luminal B breast cancer. J Natl Cancer Inst 2009;101:736-750.

105. Desmedt C, Haibe-Kains B, Wirapati P, et al. Biological processes associated with breast cancer clinical outcome depend on the molecular subtypes. Clin Cancer Res 2008;14:5158-5165.

106. Hu Z, Fan C, Oh DS, et al. The molecular portraits of breast tumors are conserved across microarray platforms. BMC Genomics 2006;7:96.

107. Hugh J, Hanson J, Cheang MC, et al. Breast cancer subtypes and response to docetaxel in node-positive breast cancer: use of an immunohistochemical definition in the BCIRG 001 trial. J Clin Oncol 2009;27:1168-1176.

108. Rouzier R, Perou CM, Symmans WF, et al. Breast cancer molecular subtypes respond differently to preoperative chemotherapy. Clin Cancer Res 2005;11:5678-5685.

109. Srour N, Reymond MA, Steinert R. Lost in translation? A systematic database of gene expression in breast cancer. Pathobiology 2008;75:112-118.

110. Allred DC. The utility of conventional and molecular pathology in managing breast cancer. Breast Cancer Res 2008;10(Suppl 4):S4.

111. Livasy CA, Karaca G, Nanda R, et al. Phenotypic evaluation of the basal-like subtype of invasive breast carcinoma. Mod Pathol 2006;19:264-271.
112. Allred DC, Wu Y, Mao S, et al. Ductal carcinoma in situ and the emergence of diversity during breast cancer evolution. Clin Cancer Res 2008;14:370-378.

113. Livasy CA, Perou CM, Karaca G, et al. Identification of a basallike subtype of breast ductal carcinoma in situ. Hum Pathol 2007;38:197-204.

114. Tamimi RM, Baer HJ, Marotti J, et al. Comparison of molecular phenotypes of ductal carcinoma in situ and invasive breast cancer. Breast Cancer Res 2008;10:R67.

115. Kok M, Linn S, van de Vijver M, et al. Estrogen receptor phenotypes defined by gene expression profiling. In: Fuqua SAW, ed. Hormone Receptors in Breast Cancer. New York: Springer; 2009:231-248.

116. Allred DC, Bryant J, Land S, et al. Estrogen receptor expression as a predictive marker of the effectiveness of tamoxifen in the treatment of DCIS: findings from NSABP protocol B-24 [abstract]. Breast Cancer Res Treat 2004;76(Suppl 1):Abstract 30.

117. Goss PE, Ingle JN, Martino S, et al. Efficacy of letrozole extended adjuvant therapy according to estrogen receptor and progesterone receptor status of the primary tumor: National Cancer Institute of Canada Clinical Trials Group MA.17. J Clin Oncol 2007;25:20062011.

118. Ellis MJ, Coop A, Singh B, et al. Letrozole is more effective neoadjuvant endocrine therapy than tamoxifen for ErbB-1 - and/ or ErbB-2-positive, estrogen receptor-positive primary breast cancer: evidence from a phase III randomized trial. J Clin Oncol 2001;19:3808-3816.

119. Fisher B, Redmond C, Brown A, et al. Adjuvant chemotherapy with and without tamoxifen in the treatment of primary breast cancer: 5-year results from the National Surgical Adjuvant Breast and Bowel Project trial. J Clin Oncol 1986;4:459-471.

120. Hutchins LF, Green SJ, Ravdin PM, et al. Randomized, controlled trial of cyclophosphamide, methotrexate, and fluorouracil versus cyclophosphamide, doxorubicin, and fluorouracil with and without tamoxifen for high-risk, node-negative breast cancer: treatment results of Intergroup Protocol INT-0102. J Clin Oncol 2005;23:8313-8321.

121. Adjuvant tamoxifen in the management of operable breast cancer: the Scottish Trial. Report from the Breast Cancer Trials Committee, Scottish Cancer Trials Office (MRC), Edinburgh. Lancet 1987;2:171-175.

122. Lippman ME, Allegra JC. Lack of estrogen receptor associated with an increased response rate to cytotoxic chemotherapy in metastatic breast cancer? Recent Results Cancer Res 1980;71:155161.

123. U.S. Department of Health \& Human Services, Nation Institutes of Health. NIH Consensus Development Program: Adjuvant Therapy for Breast Cancer. November 2000. Available at: http:// consensus.nih.gov/2000/2000AdjuvantTherapyBreastCancer114 html.htm Accessed August 2, 2009.

124. Carlson RW, Allred DC, Anderson BO, et al. NCCN Clinical Practice Guidelines in Oncology: Breast Cancer. J Natl Compr Canc Netw 2009;7:122-192.

125. Albain K, Barlow W, O'Malley F, et al. Concurrent (CAFT) versus sequential (CAF-T) chemohormonal therapy (cyclophosphamide, doxorubin, 5-fluorouracil, tamoxifen) versus $\mathrm{T}$ alone for postmenopausal node positive estrogen (ER) and/ or progesterone $(\mathrm{PgR})$ receptor-positive breast cancer: mature outcomes and new biologic correlates on phase III Intergroup trial 0100 [abstract]. Presented at the San Antonio Breast Cancer 
Estrogen Receptor and Progesterone Receptor Testing in Breast Cancer

Symposium; December 8-11, 2004; San Antonio, Texas. Abstract LBA37.

126. Goldhirsch A, Ingle JN, Gelber RD, et al. Thresholds for therapies: highlights of the St Gallen International Expert Consensus on the Primary Therapy of Early Breast Cancer 2009. Ann Oncol 2009;20:1319-1329.

127. Goldhirsch A, Wood WC, Gelber RD, et al. Progress and promise: highlights of the international expert consensus on the primary therapy of early breast cancer 2007. Ann Oncol 2007;18:11331144.

128. Simmons C, Miller N, Geddie D, et al. Changes in tumor receptor status with time: a prospective study assessing the impact of obtaining confirmatory biopsy at metastatic recurrence on patient management [abstract]. Presented at the 2008 ASCO Breast Cancer Symposium; September 5-7, 2008; Washington, DC. Abstract 124.

129. Guarneri V, Giovannelli S, Ficarra G, et al. Comparison of HER-2 and hormone receptor expression in primary breast cancers and asynchronous paired metastases: impact on patient management. Oncologist 2008;13:838-844.

130. Broglio K, Moulder SL, Hsu L, et al. Prognostic impact of discordance/concordance of triple-receptor expression between primary tumor and metastasis in patients with metastatic breast cancer [abstract]. J Clin Oncol 2008;26(Suppl 1):Abstract 1001.

131. Zheng WQ, Lu J, Zheng JM, et al. Variation of ER status between primary and metastatic breast cancer and relationship to p53 expression. Steroids 2001;66:905-910.

132. Rhodes A, Jasani B, Balaton AJ, et al. Frequency of oestrogen and progesterone receptor positivity by immunohistochemical analysis in 7016 breast carcinomas: correlation with patient age, assay sensitivity, threshold value, and mammographic screening. J Clin Pathol 2000;53:688-696.

133. Rhodes A, Jasani B, Balaton AJ, et al. Study of interlaboratory reliability and reproducibility of estrogen and progesterone receptor assays in Europe. Documentation of poor reliability and identification of insufficient microwave antigen retrieval time as a major contributory element of unreliable assays. Am J Clin Pathol 2001;115:44-58.

134. Chebil G, Bendahl PO, Idvall I, Ferno M. Comparison of immunohistochemical and biochemical assay of steroid receptors in primary breast cancer-clinical associations and reasons for discrepancies. Acta Oncol 2003;42:719-725.

135. Layfield LJ, Goldstein N, Perkinson KR, Proia AD. Interlaboratory variation in results from immunohistochemical assessment of estrogen receptor status. Breast J 2003;9:257-259.

136. Regitnig P, Reiner A, Dinges HP, et al. Quality assurance for detection of estrogen and progesterone receptors by immunohistochemistry in Austrian pathology laboratories. Virchows Arch 2002;441:328-334.

137. Diaz LK, Sneige N. Estrogen receptor analysis for breast cancer: current issues and keys to increasing testing accuracy. Adv Anat Pathol 2005;12:10-19.

138. Taylor CR, Levenson RM. Quantification of immunohistochemistry - issues concerning methods, utility and semiquantitative assessment II. Histopathology 2006;49:411-424.

139. Yaziji H, Taylor CR, Goldstein NS, et al. Consensus recommendations on estrogen receptor testing in breast cancer by immunohistochemistry. Appl Immunohistochem Mol Morphol 2008;16:513-520.

140. Walker RA. Immunohistochemical markers as predictive tools for breast cancer. J Clin Pathol 2008;61:689-696.
141. Douglas-Jones AG, Collett N, Morgan JM, Jasani B. Comparison of core oestrogen receptor (ER) assay with excised tumour: intratumoral distribution of ER in breast carcinoma. J Clin Pathol 2001;54:951-955.

142. Park SY, Kim KS, Lee TG, et al. The accuracy of preoperative core biopsy in determining histologic grade, hormone receptors, and human epidermal growth factor receptor 2 status in invasive breast cancer. Am J Surg 2009;197:266-269.

143. Gown AM. Current issues in ER and HER2 testing by IHC in breast cancer. Mod Pathol 2008;21(Suppl 2):S8-15.

144. Hodi Z, Chakrabarti J, Lee AH, et al. The reliability of assessment of oestrogen receptor expression on needle core biopsy specimens of invasive carcinomas of the breast. J Clin Pathol 2007;60:299_ 302.

145. Nkoy FL, Hammond E, Rees W, et al. Day of surgery affects estrogen receptor test results in women with breast cancer [abstract]. Presented at the San Antonio Breast Cancer Symposium; December 8-11, 2005; San Antonio, Texas. Abstract 5107.

146. Goldstein NS, Ferkowicz M, Odish E, et al. Minimum formalin fixation time for consistent estrogen receptor immunohistochemical staining of invasive breast carcinoma. Am J Clin Pathol 2003;120:86-92.

147. Rhodes A, Jasani B, Balaton AJ, Miller KD. Immunohistochemical demonstration of oestrogen and progesterone receptors: correlation of standards achieved on in house tumours with that achieved on external quality assessment material in over 150 laboratories from 26 countries. J Clin Pathol 2000;53:292-301.

148. Pertschuk LP, Masood S, Simone J, et al. Estrogen receptor immunocytochemistry in endometrial carcinoma: a prognostic marker for survival. Gynecol Oncol 1996;63:28-33.

149. Gown AM. Unmasking the mysteries of antigen or epitope retrieval and formalin fixation. Am J Clin Pathol 2004;121:172-174.

150. Riera J, Simpson JF, Tamayo R, Battifora H. Use of cultured cells as a control for quantitative immunocytochemical analysis of estrogen receptor in breast cancer. The Quicgel method. Am J Clin Pathol 1999;111:329-335.

151. Sompuram SR, Kodela V, Ramanathan H, et al. Synthetic peptides identified from phage-displayed combinatorial libraries as immunodiagnostic assay surrogate quality-control targets. Clin Chem 2002;48:410-420.

152. Sompuram SR, Kodela V, Zhang K, et al. A novel quality control slide for quantitative immunohistochemistry testing. J Histochem Cytochem 2002;50:1425-1434.

153. Sompuram SR, Vani K, Bogen SA. A molecular model of antigen retrieval using a peptide array. Am J Clin Pathol 2006;125:91-98.

154. Vani K, Sompuram SR, Fitzgibbons P, Bogen SA. National HER2 proficiency test results using standardized quantitative controls: characterization of laboratory failures. Arch Pathol Lab Med 2008;132:211-216.

155. Schnitt SJ. Estrogen receptor testing of breast cancer in current clinical practice: what's the question? J Clin Oncol 2006;24:17971799 .

156. Umemura S, Itoh J, Itoh $\mathrm{H}$, et al. Immunohistochemical evaluation of hormone receptors in breast cancer: which scoring system is suitable for highly sensitive procedures? Appl Immunohistochem Mol Morphol 2004;12:8-13. 